\title{
Long-term dispersal of heavy metals in a catchment affected by historic lead and zinc mining
}

\author{
Dariusz Ciszewski • Urszula Kubsik • \\ Urszula Aleksander-Kwaterczak
}

Received: 24 August 2011 / Accepted: 19 June 2012 / Published online: 8 July 2012

(C) The Author(s) 2012. This article is published with open access at Springerlink.com

\begin{abstract}
Purpose The Matylda catchment, in southern Poland, was polluted by the discharge of mine waters from a lead and zinc mine that inundated parts of a valley floor and caused the accumulation of metal-polluted sediments. After a partial reclamation of the mine site in the early 1980 s, polluted sediments continue to accumulate on downstream floodplains and in fishponds. The aim of this study was to reconstruct the changes in metal dispersal during 100 years of mining and during the 40 -year post-mining period and to propose a strategy for pollution mitigation in the area.

Materials and methods Analyses of $\mathrm{Cu}, \mathrm{Cd}, \mathrm{Pb}, \mathrm{Zn}, \mathrm{Mn}$, $\mathrm{Ca}, \mathrm{Mg}$ and $\mathrm{Fe}$ concentrations, speciation of heavy metals and mineralogical analyses were undertaken on overbank sediment cores and in stream sediments. Concentrations of the same elements and macro-ions soluble in stream waters were also determined.

Results and discussion Concentrations of $\mathrm{Zn}, \mathrm{Cd}$ and $\mathrm{Pb}$ in the sediment profiles vary between 40,000 and 55,000, 300 and 600 and 30,000 and $50,000 \mathrm{mg} \mathrm{kg}^{-1}$, respectively. Changes of metal concentrations and the stratigraphy of sediments from the floodplains, stream channels and fishponds suggest rapid changes of metal loads migrating downstream during both the mining and post-mining periods. Since the time of mine closure, fine-grained, mine-derived sediments (ca. $12 \mathrm{~cm}$ thick) have been the main source of pollution of post-mining sediments and surface waters. Closure of the mine was followed by a relatively short period of rapid redistribution of sediment-associated heavy metals in
\end{abstract}

Responsible editor: Marcel van der Perk

D. Ciszewski $(\square) \cdot U$. Kubsik $\cdot$ U. Aleksander-Kwaterczak

AGH University of Science and Technology,

Mickiewicza St. 30,

30-059 Krakow, Poland

e-mail: ciszewski@geol.agh.edu.pl the stream channel. Since the 1980s, the floodplain and fishponds have received a constant supply of metals. It contrasts with the slow sediment accretion rate and a rapid decrease of metal concentrations in floodplain pools due to dilution by decomposed leaf litter. A fivefold increase of $\mathrm{Cd}$ content in waters over the $4.6 \mathrm{~km}$ reach of the Matylda stream indicates continuous leaching of this element from the contaminated valley floor.

Conclusions Unsuccessful mine site rehabilitation is due to leaching of mine-originated sediments dispersed over the valley bottom. However, the rate of metal remobilization over the last 40 years is low because of the small thickness and widespread anoxic conditions that prevail within both recent and mine-originated sediments and the alkaline $\mathrm{pH}$ of stream water, which reduces metal mobility. Distribution of the contaminated layer over a large area of the valley bottom precludes cost-efficient catchment rehabilitation.

Keywords Heavy metals $\cdot$ Mining $\cdot$ Pollution ·

Rehabilitation · River sediments

\section{Introduction}

Ore extraction and processing produces large quantities of metal-contaminated wastes that can release heavy metals long after the cessation of mining. Metals stored in tailings at former metal mines can be dispersed to surrounding soils, streams and groundwaters due to erosion, weathering and leaching processes (Marques et al. 2001; Lee at al. 2005; Lintnerova et al. 2008; Rodriguez et al. 2009). Many of these studies show that metal stabilisation and localisation at mine sites is the only cost-effective remediation option for controlling the dispersal of metal contaminants in the environment (Mulligan et al. 2001). However, some metal contaminants escape either during ore mining or processing and 
are dispersed for much longer distances, affecting the quality of water and sediment (Ciszewski 1998). Also, in some historical mining areas, metal ores when extracted were processed with running water and this introduced metalliferous wastes into river systems (Walling et al. 1998). It is estimated that in some catchments, as much as one third of the ores exploited in the eighteenth and nineteenth centuries is presently stored in overbank deposits (Dennis et al. 2009). Former metal mining with inefficient ore enrichment techniques, and a lack of elementary concern for the environment, has resulted in a substantial legacy of heavy metal contamination persisting in channel and overbank sediments. In many catchments affected by metal mining, severe sediment contamination is observed in channels and floodplains over relatively short distances (i.e. several kilometres) downstream of former mines (Miller 1997; Byrne et al. 2010). Metals stored within these river reaches during the mining period can be remobilized and transported downstream, with the rate depending on their chemical associations and rates of river bank erosion; the latter is, in turn, controlled by rainfall or hydrological regime (Harrison et al 2003; Pulford et al. 2008). The rate of metal remobilization can limit the effectiveness of mine site rehabilitation (Taylor 2007). Heavy metal leaching from floodplain sediments can be estimated not only from high total metal concentrations but also from the proportion of metals in the most mobile fractions (Aleksander-Kwaterczak and Helios-Rybicka 2009). Moreover, observation of discrepancies between metal peaks in consecutive vertical profiles of overbank sediments and pollution history may indicate metal migration. The intensity of metal mobilisation, related to frequent floodplain inundation, is much higher than usually observed in uninundated soils, with little attention paid to the environmental significance of this process (Ciszewski et al. 2008). Moreover, metal redistribution in vertical profiles, which reflects to some extent metal transfer from sediments to surface waters, is also related to changes in redox conditions and precipitation with Fe hydroxides (Cappuyns and Swennen 2004; Kraus and Wiegand 2006). Investigations of metal mine-contaminated catchments indicate the role of channel and floodplain sediments as an important diffuse metal source (Owens and Walling 2003; Mighanetara et al. 2009). This should be recognised in the context of their spatial variability and the rate of post-depositional metal migration, so as to formulate management and site remediation strategies (Hudson-Edwards et al. 1998).

This study focuses on the Matylda stream (ca. $10 \mathrm{~km}$ long), which was affected by the historical Matylda lead $(\mathrm{Pb})$ and zinc $(\mathrm{Zn})$ mine in Chrzanów in Silesian Upland, southern Poland. This mine mainly exploited galena and sphalerite, accompanied by iron sulphides, cerrusite and smithsonite, from ore-bearing Triassic dolomites. The ore grade was defined as low with the $\mathrm{Zn}$ content $<40,000 \mathrm{mg} \mathrm{kg}^{-1}$ and $\mathrm{Pb}$ content of about 15,000 mg kg${ }^{-1}$ (Górecka et al. 1996). The mine was established in 1850 in the upper section of the valley and pumped up to $10,000 \mathrm{dm}^{3} \mathrm{~s}^{-1}$ of mine waters to the meandering $2 \mathrm{~m}$ wide Matylda stream. Relatively high mine water discharges caused waterlogging of the low-slope reaches of the valley bottom. The mine was prone to inundation from the local karstic aquifer, and inflows of waters to the mine interrupted operations several times. In 1926, the mine was expanded and the Matylda stream was converted into a trapezoidal straight channel. Nevertheless, Matylda stream water was supplied to fish ponds situated in the upper and middle valley reaches. These ponds resulted in raised local groundwater levels and the development of wetland communities in their surroundings. After the closure of the mine in the 1930s, production started again in 1953 and the mine extension was accompanied by channel training works. The production of $100,000-140,000 \mathrm{t}$ year $^{-1}$ of $\mathrm{Pb}$ and $\mathrm{Zn}$ ores was two times higher than before World War II and several times higher than in the nineteenth century (Szuwarzyński 2000). The ores were pre-selected underground and enriched in the ore processing plant, whereas wastes were dumped close to the mine. Since exhaustion of the ores and closure of the mine in 1972, the Matylda stream has naturally drained the catchment. Mine tailings were partially reclaimed in the 1980s and the concrete channel lining of the upper Matylda section precluded seepage from tailings remnants to the stream. Moreover, the Matylda stream in its lower reach was converted into a concrete-lined channel constraining sediment deposition to the mouth section which has a very low gradient. The lower reach of the stream receives, from a tributary, effluent from a sewage treatment plant, which exceeds the discharge of the Matylda stream. At present, the stream is moderately polluted with storm waters and municipal sewages from some buildings of Chrzanów City (40,000 inhabitants), which is situated in the upper section of the catchment. Reconstruction of the Matylda channel in 1953 formed a channel $1.5 \mathrm{~m}$ wide with a uniform channel bottom and gentle banks slope, which caused preservation of the closed floodplain depressions to be filled permanently with water. Dikes, built within the low-gradient valley of the middle and upper reach, provide obstacles to the natural drainage and cause periodic inundation of the valley bottom. Fishponds still receive water from the Matylda stream during high water stages. At present, the fluvioglacial sandy deposits filling the valley bottom are overgrown with riparian forest which is dominated by of black alder.

The aims of this study were (1) to reconstruct the changes in metal dispersal since the $\mathrm{Pb}$ and $\mathrm{Zn}$ mining era in the Matylda catchment and (2) to formulate a strategy for pollution mitigation in the investigated area. This was achieved by the investigation of the metal pollution record in vertical profiles and in channel surface sediments, as well as by water pollution monitoring. In this study, we assumed that metal mobility in different locations of the Matylda 
floodplain is reflected in vertical profiles, their chemical forms and concentrations in receiving waters.

\section{Materials and methods}

Sediment profiles were collected at two study reaches in the Matylda valley (A and B, Fig. 1). In both these reaches, the valley bottom is relatively wide and there are fish ponds supplied with Matylda stream waters via partially destroyed side channels and during high water. In each reach, cores up to $0.5 \mathrm{~m}$ long were sampled with a hand-held piston corer at four locations of different local topography and ground water level, namely, from in-channel alluvial levels, periodically inundated floodplain, permanent floodplain pools and from near the bank zone of fish ponds. Additionally, one profile $(\mathrm{C} ; 30 \mathrm{~cm}$ long) was sampled from the mouth of the channel. Cores were sliced into $1-6 \mathrm{~cm}$ increments, and their macroscopic features were determined: colour, estimated content and degradation of organic particles and grainsize composition. Samples were split into two subsamples: one for total metal concentrations and one for other analyses. For the latter, particularly those of small thickness and amount, samples were combined with other samples from the same stratigraphic unit of similar macroscopic features; subsequently, composite samples were analysed for Eh and $\mathrm{pH}$, loss-on-ignition and metal partitioning. Subsamples for $\mathrm{X}$-ray diffraction analysis (XRD) were selected from vertical profiles, based on the obtained metal distribution, as well as sample volume, and for these reasons are in some cases different from the sample depths selected for metals partitioning. Anticipating that peaks in heavy metal concentrations in the sediment profiles represent mining period, subsamples were taken from: pre-mining (one sample before the main rise of metal concentrations), mining (three samples with the highest metal contents) and post-mining (four samples after a drop in metal concentrations) periods. These assumptions were to document the change in mineral composition from the "pristine" to mine-related deposits and to determine the presence of mine-originated minerals in the sediments of the post-mining period.

To estimate the contemporary metal content of the streambed sediments, seven grab samples of channel sediments were collected and three vertical profiles were sampled from four locations over a distance of $4.6 \mathrm{~km}$ : two samples were collected from the upper (M1) and two from the middle reach (M3) close to the profile locations, and two samples were collected mid-way between these sampling locations (M2) (see Fig. 1). The lower location (M4) was situated downstream from the lower ponds, just above the confluence with the tributary discharging effluents from the sewage treatment plant in Libiąż (see black arrow on Fig. 1). Sampling from the lower reach of the lined Matylda channel was impossible as far as the mouth section, where the low gradient and abundant aquatic plants favoured sediment deposition. At each sampling location, active (mid-channelM1a, M2a and M3a) and near-bank (M1b, M2b, M3b and M4b) channel sediments were sampled, except site M4a, where the abundant plant cover prevented sampling. In total, seven grab samples and three profiles from the stream channel and six profiles from ponds and from the floodplain were sampled. By comparing the metal content in the grab samples with the metal content in the vertical sediment profiles from the mining era, the rate of post-mining changes in sediment pollution was determined. At all four channel locations, samples of stream waters were sampled 11 times over 1 year in order to detect levels of heavy metals, which may originate from contaminated sediments. Moreover, a general hydrochemistry of stream waters was characterised. On each sampling occasion, to determine macro-ions content, 0.51 of water content was poured into a polypropylene bottle, and $0.04 \mathrm{dm}^{3}$ of water designed for the heavy metals analyse was passed
Fig. 1 Research area and location of sampling points: 1 wetlands, 2 roads, 3 closed Matylda mine, 4 built-up area, 5 forest roads, 6 fish ponds, 7 terrace slopes, 8 railways, 9 forest, 10 sampled profiles, 11 channel sediment sampling points, the black arrow indicates the discharge point from STP in Libi

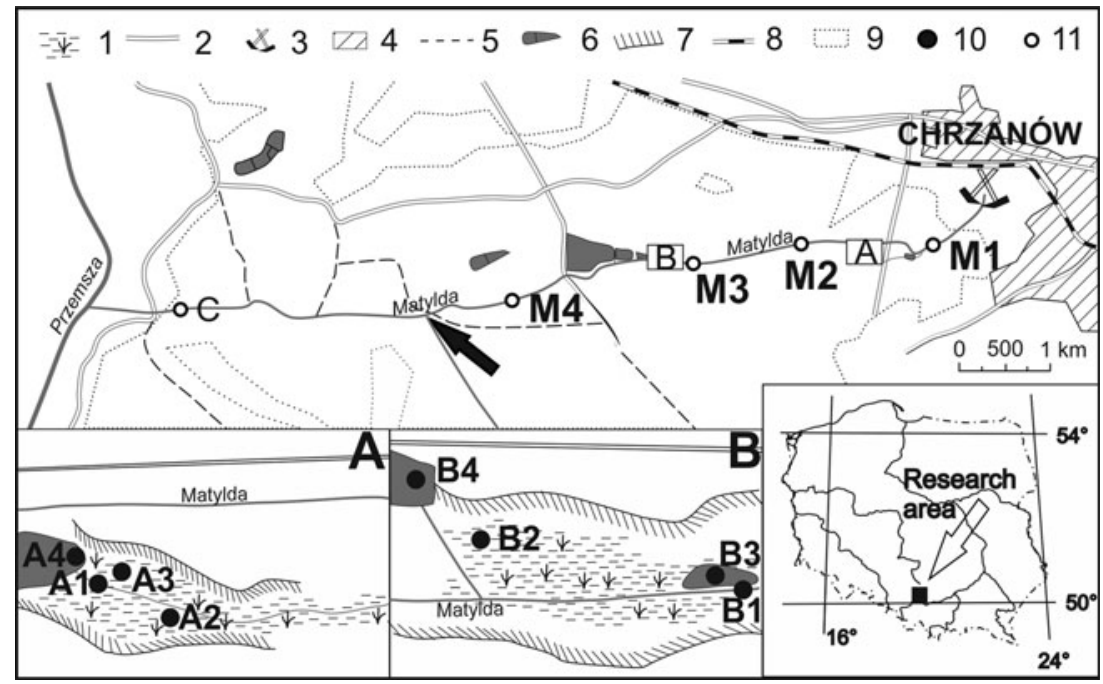


through the $0.45-\mu \mathrm{m}$ pore-sized filters into the polyethylene container and acidified to $\mathrm{pH}$ less than 2 with ultrapure $\mathrm{HNO}_{3}$.

Inorganic anions were analysed within $48 \mathrm{~h}$ using ion chromatography (DIONEX 1000). Water samples were filtered immediately before analysis through $0.45 \mu \mathrm{m}$ filters and concentrations of ions $\left(\mathrm{Cl}^{-}\right.$, $\mathrm{NO}^{-3}, \mathrm{SO}_{4}{ }^{-2}, \mathrm{PO}_{4}{ }^{-3}$ and $\left.\mathrm{CO}_{3}{ }^{-2}\right)$ and elements $(\mathrm{Ca}$, $\mathrm{Mg}, \mathrm{Na}$ and $\mathrm{K}$ ) were determined. Concentrations of metals ( $\mathrm{Zn}, \mathrm{Cd}, \mathrm{Cu}, \mathrm{Pb}, \mathrm{Fe}, \mathrm{Ca}, \mathrm{Mg}$ and $\mathrm{Mn}$ ) were measured with an inductively coupled plasma-mass spectrometer (Perkin Elmer ELAN 6100). From each sediment sample, the silt-clay fraction $(<0.063 \mathrm{~mm})$ was wet-separated. Metals were brought into solution in Teflon bombs using a microwave digestion technique $\left(10 \mathrm{~cm}^{3}\right.$ of $65 \% \mathrm{HNO}_{3}$ and $2 \mathrm{~cm}^{3}$ of $30 \% \mathrm{H}_{2} \mathrm{O}_{2}$ ). To assess the active dispersion of metals with water in waterlogged soils and sediments in the catchment, the speciation of metals was determined in selected samples from the channel bed and from the vertical profiles. Metal speciation was determined using a standard BCR sequential extraction procedure to extract heavy metals in four geochemical phases: (1) acid extractable, exchangeable and bound to carbonates; (2) reducible, bound to $\mathrm{Fe}$ (iron) and $\mathrm{Mn}$ (manganese) oxides; (3) oxidisable, bound to organic and sulphide compounds and (4) the residual fraction (Rauret et al 1999). The concentrations of metals were determined using a flame atomic absorption spectrometer (AAS). Standard reference materials (Canadian Waters Hamilton-20) were employed to determine the accuracy of anion analyses. Metal analyses were obtained according to the standard certified analytical quality control procedure (PN-EN ISO 17294-1:2007). XRD measurements were performed using a diffractometer equipped with a diffractedbeam monochromator using $\mathrm{CuK} \alpha$ radiation $(35 \mathrm{kV}, 30 \mathrm{~mA}$, step size $0.05^{\circ} \Theta$ ).

In addition, to determine the effect of leaf-fall on organic matter contamination (mostly consisting of leaves), leaf samples of five to six alders from each of the sediment sampling areas A and B (see Fig. 1) were collected. One reference sample was taken from outside of the valley bottom. Metals were brought into solution using a microwave digestion technique $\left(10 \mathrm{~cm}^{3}\right.$ of $65 \% \mathrm{HNO}_{3}$ and $2 \mathrm{~cm}^{3}$ of $30 \% \mathrm{H}_{2} \mathrm{O}_{2}$ ) and their concentrations were determined using AAS SOLAAR.

\section{Results}

\subsection{Metal distribution in vertical sediment profiles}

Concentrations of heavy metals in the investigated profiles were extremely variable. Generally, peaks of $\mathrm{Pb}, \mathrm{Zn}$ and $\mathrm{Cd}$ were in the range 30,000-50,000, 40,000-55,000 and 300 $600 \mathrm{mg} \mathrm{kg}^{-1}$, respectively (Fig. 2). The lowest values approach mean metal concentrations in forest soils of this area obtained from a depth of $0.8-1 \mathrm{~m}$ during geochemical mapping by the State Geological Survey. These values can be considered as the local geochemical background representative of Pleistocene fluvioglacial sandy deposits, which cover earlier deposits with a layer up to several tens of metres thick (Pasieczna 2008). The maximum concentrations of $\mathrm{Pb}, \mathrm{Zn}$ and $\mathrm{Cd}$ in sediment profiles are almost 1,000 times higher than for the geochemical background values. In most profiles, there are also distinct peaks of $\mathrm{Cu}$ concentrations, with an extreme value $\left(1,385 \mathrm{mg} \mathrm{kg}^{-1}\right)$ in the surface sediments of the A3 profile. In other profiles, maximum $\mathrm{Cu}$ concentrations are $<100-250 \mathrm{mg} \mathrm{kg}^{-1}$ with most of samples being weakly polluted or unpolluted when compared with geochemical background values. In contrary to $\mathrm{Cu}$, in all profiles, there are high $\mathrm{Fe}$ concentrations with peaks varying between 40,000 and $70,000 \mathrm{mg} \mathrm{kg}^{-1}$ and minimum values are generally $>10,000 \mathrm{mg} \mathrm{kg}^{-1}$.

There is some regularity in metal distribution in similar sampling locations in the investigated upper and middle Matylda sections (A and B, Fig. 1). Profile A1 represents sediments over $40 \mathrm{~cm}$ thick accumulated in a small side stream channel with periodic slow water flow not exceeding $1-2 \mathrm{dm}^{3} \mathrm{~s}^{-1}$. This location is situated in the mouth section of the channel before entering the fishpond. The flow conditions favour deposition of very fine-grained sediment with the organic matter content $>60 \%$ in the surface 15 -cm-thick layer. Below this, the content of silt decreases and at the bottom there are sandy sediments with a very low organic matter content $(<2 \%)$. The changes in stratigraphy are associated with changes in $\mathrm{Pb}, \mathrm{Zn}$ and $\mathrm{Cd}$ content, which is several times higher in the sandy bottom than in the top layer of fine sediments. The other channel profile (B1; from the middle Matylda section) represents sediments of the narrow alluvial level, which accumulated to a height of about $30 \mathrm{~cm}$ over the streambed. Here, the sediment consists mainly of sandy silts, overlying fine gravels, which are observed also in the bed. Changes of organic matter content show the same tendency as in the upper section of the stream channel, increasing from $<2 \%$ at the bottom to about $20 \%$ at the surface. As in the previous profile, $\mathrm{Pb}, \mathrm{Zn}$ and $\mathrm{Cd}$ concentrations show an opposite tendency with a progressive decrease towards the most recent deposits. These metal concentrations are generally lower than in the A1 profile. In both profiles, $\mathrm{Cu}$ concentrations show peaks, which in the upper Matylda section occur at a higher level than in the profile from the middle reach. Fe content shows no regular changes throughout both profiles.

In contrast to profiles from stream channels, floodplain profiles A2 and B2 (see Figs. 2 and 3) show completely different distribution pattern. In A2, sediments contaminated 
A1
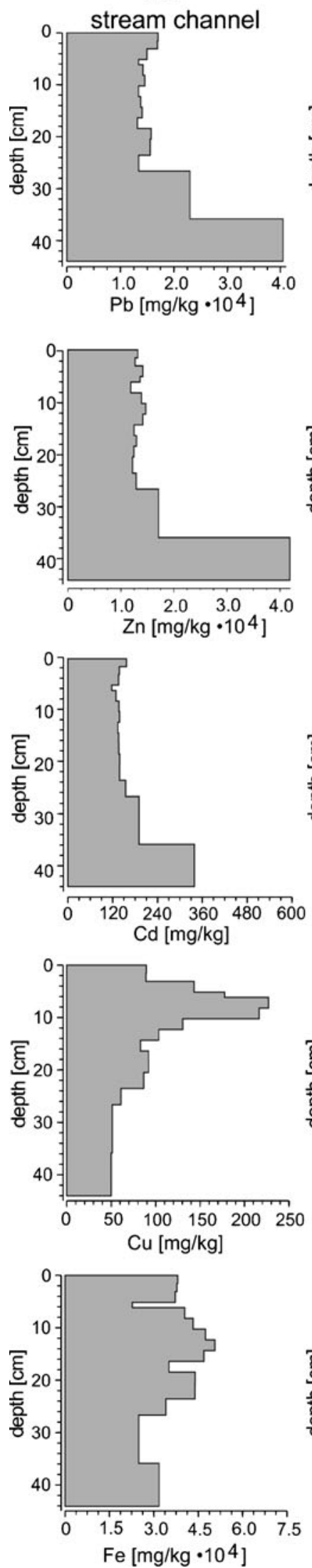

A2
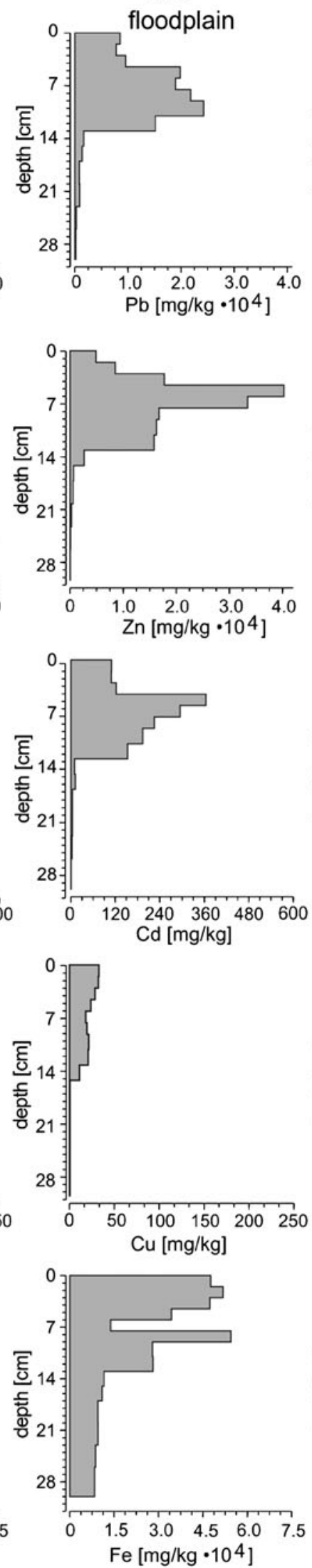

A3
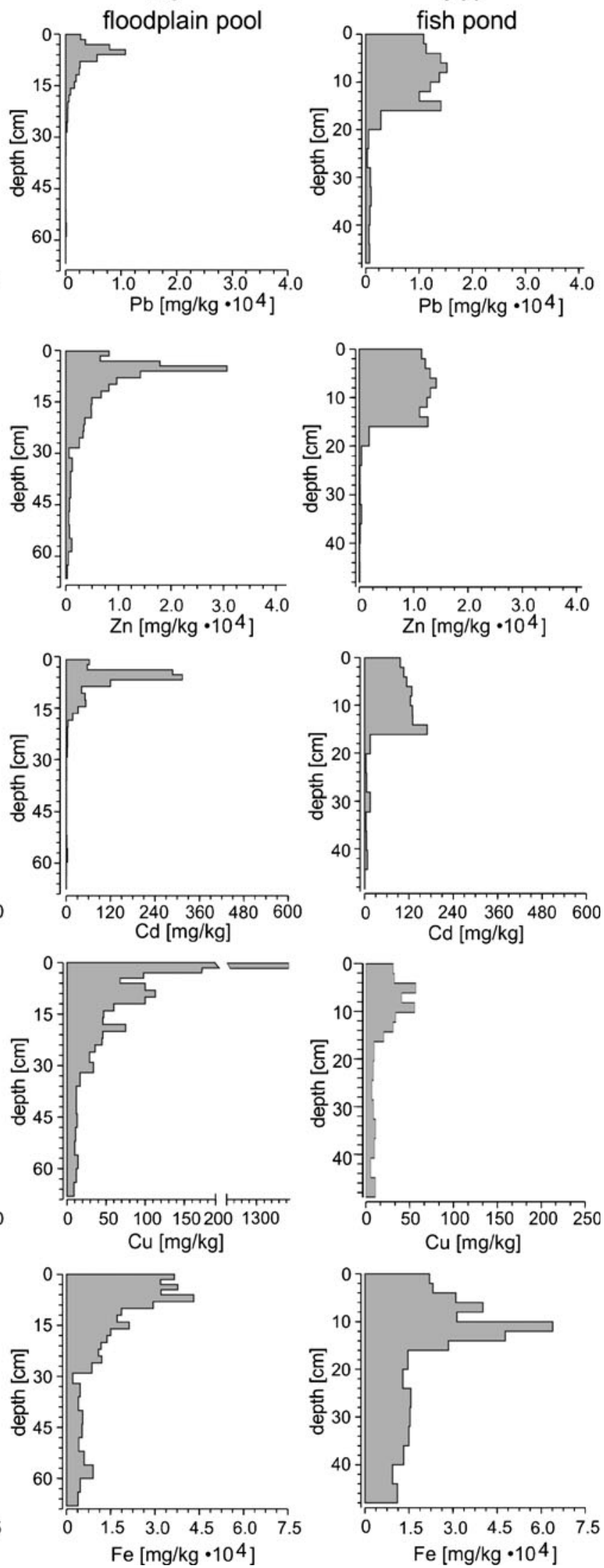

A4
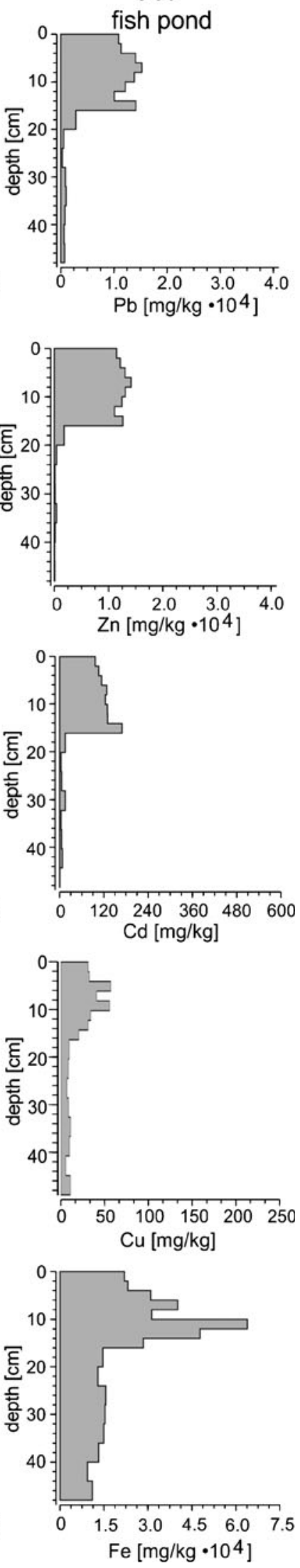

Fig. 2 Distribution of heavy metals in the vertical profiles sampled in the upper section of the Matylda catchment 
with $\mathrm{Pb}, \mathrm{Zn}$ and $\mathrm{Cd}$ occur solely in the top $13 \mathrm{~cm}$. The growth of the metals content is rapid and takes place in the 4-cm-thick mineral layer of silt-clay fraction (Fig. 4). The maximum content of $\mathrm{Pb}$ occurs in this layer whereas peaks of $\mathrm{Zn}$ and $\mathrm{Cd}$ occur in the bottom part of the overlying top organic layer with the very high (ca. $50 \%$ ) organic matter content. It contrasts with an organic matter content of $12 \%$ for the silt-clay sediments. The content of these elements decreases in the most recent surface deposits. The complex of organic and mineral layers is underlain by virtually unpolluted sediments: the 7 -cm-thick organic layer with organic content up to $30 \%$, and the grey, clay-silt layer with no organic matter. Profile B2 from the middle reach is situated further from the stream channel than B1; however, both are seasonally inundated to a depth exceeding $0.5 \mathrm{~m}$. Generally, the B2 sediments are more polluted in respect to maximum concentrations and thickness of the heavy polluted layer. The values for $\mathrm{Pb}, \mathrm{Zn}$ and $\mathrm{Cd}$ exceed 30,000, 60,000 and $400 \mathrm{mg} \mathrm{kg}{ }^{-1}$, respectively. The profile stratigraphy is similar to that from the previous profile; bottom organic sediments with organic detritus and losses on ignition (LOI) values, which vary between 46 and $75 \%$, are overlain by yellow-grey, clay-silty sediment with about $12 \%$ organic matter content. Again, this mineral layer is the most polluted with $\mathrm{Pb}, \mathrm{Zn}$ and $\mathrm{Cd}$. The top $8 \mathrm{~cm}$ is less polluted with these metals and contains a small peak of $\mathrm{Cu}$. Peak Fe concentrations occur just below the mineral layer in B2 and in B1 above the most polluted layer. The concentrations of $\mathrm{Ca}$ and $\mathrm{Mg}$ in the stream channel and floodplain profiles (A1, A2, B1 and B2) are given on Fig. 5. Observed changes of both elements are similar in each profile and these resemble of mine-originated metals.

Profiles A3 and B3 were sampled from the permanent water pools situated in floodplain depressions of the sampled upper and lower Matylda catchment. Each of these basins is about $1 \mathrm{~m}$ deep and extends over several hundreds square metres. The upper pool is periodically supplied via the Matylda distributary channel and zone of extensive plant cover. Profile A3 (see Fig. 2) was sampled from the middle of this basin and consists of two distinct sediment layers. The upper one is $29 \mathrm{~cm}$ thick and consists mainly of organic silts with LOI values varying between 27 and $63 \%$. This layer is moderately contaminated, with peaks of all heavy metals in the top $6 \mathrm{~cm}$, with the highest $\mathrm{Zn}, \mathrm{Cd}$ and $\mathrm{Pb}$ values in the 2 -cm-thick silty dark-yellow layer. The content of all metals is of contrastingly low value in the lower, $>30 \mathrm{~cm}$ long profile section of fine-grained sands. Here, the metal concentrations, except for $\mathrm{Zn}$, are similar to the local geochemical background values (Pasieczna 2008). Zn concentrations are two to four times higher than the background. The content of organic matter is minimal.
Profile B3 from the middle of the catchment (see Fig. 3) is situated in the floodplain pool a few metres from the Matylda channel; however, a low artificial dyke limits direct flow from the channel to the basin. Sediments in the profile consist of silty muds with an organic matter content of ca. $8-9 \%$, which increases to $17 \%$ at the surface $6 \mathrm{~cm}$. In this layer, $\mathrm{Pb}, \mathrm{Zn}$ and $\mathrm{Cd}$ concentrations drop to the lowest values observed in the surface sediments of all profiles: $1,545,4,406$ and $1.6 \mathrm{mg} \mathrm{kg}^{-1}$, respectively. At $6-10 \mathrm{~cm}$ depth, there is the clay layer with the highest $\mathrm{Zn}$ and $\mathrm{Cd}$ content in all investigated sediments. $\mathrm{Pb}$ levels in this layer are relatively low and reach about $20,000 \mathrm{mg} \mathrm{kg}^{-1}$ and the $\mathrm{Cu}$ peak is ca. $100 \mathrm{mg} \mathrm{kg}^{-1}$. Fe concentrations rise slowly from the bottom towards the top.

The upper fishpond (A, Fig. 1) was created in the 1920s probably for utilisation of mine waters from the extended mine. The pond was rebuilt in 1974 after mine closure, and the bottom sediments were removed and stored overbank. Since this time, the upper part of this pond has been left for natural reed succession and the pond was not emptied. Profile A4 was sampled in the near-bank reed zone a few metres from the bank. The upper $16 \mathrm{~cm}$ of the profile consists of fine-grained sediments with high organic matter content (about $50 \%$ at the surface). Below, there is a layer with poorly decomposed organic remains. This organic layer has a Fe content of ca. 70,000 mg kg-1 and is contaminated with $\mathrm{Pb}, \mathrm{Zn}$ and $\mathrm{Cd}$ concentrations exceeding 15,000, 14,000 and $169 \mathrm{mg} \mathrm{kg}^{-1}$, respectively (see Fig. 2). Less contaminated sediments begin to decrease and contain mostly silts with sands. However, the metal content drops sharply between 16 and $20 \mathrm{~cm}$; average $\mathrm{Cd}, \mathrm{Zn}$ and $\mathrm{Pb}$ concentrations in the lower levels vary between 15 and 4, 400 and 60 and 1,000 and $300 \mathrm{mg} \mathrm{kg}^{-1}$, respectively.

The small fishpond in the middle Matylda section is the first in the cascade of ponds (see Fig. 1) and served as a sediment trap when supplied with Matylda mine waters. After the cessation of mining, sediments were not removed; however, pond banks were pushed back, reinforced and the water level raised. The sediment profile (B4, Fig. 3) was situated on the near-bank shelf covered with organic sediments, about $1 \mathrm{~m}$ from the bank. The profile comprises the sediment sequence with organic sediments on the top and sands at the bottom. The horizon at $21 \mathrm{~cm}$ splits the sediments into a strongly polluted upper part (with $\mathrm{Cd}, \mathrm{Pb}$ and Zn concentrations $>150,5,000$ and $15,000 \mathrm{mg} \mathrm{kg}^{-1}$, respectively, and with a marked $\mathrm{Cu}$ peak at depth $9 \mathrm{~cm}$ ) and a lower part with the metals content lower by one order of magnitude. Also, note the fairly regular decrease of the investigated metals in the upper, organic layer toward the profile top.

Profile C (30 cm long) represents sediments of the lower reach of the Matylda stream overgrown with aquatic plants, which serves as a sediment trap. It is composed of two main 
B1
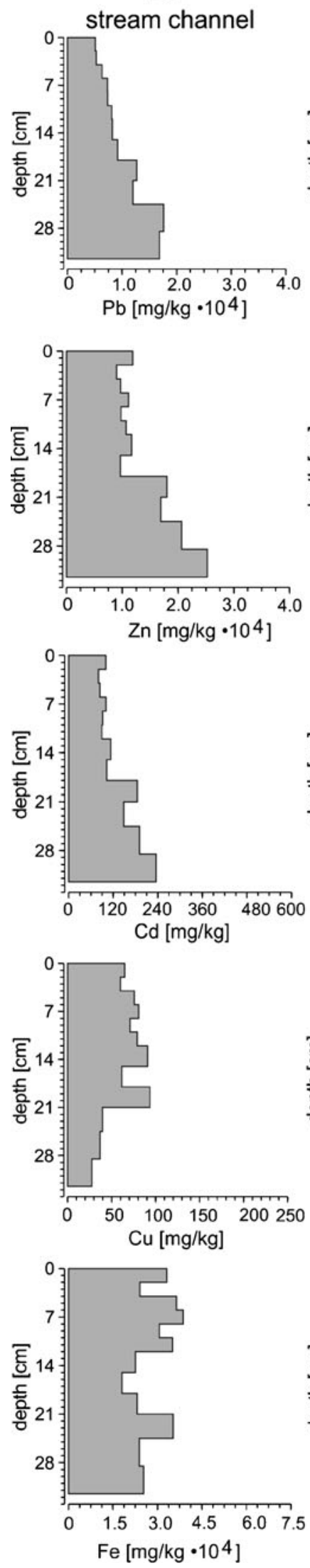

B2
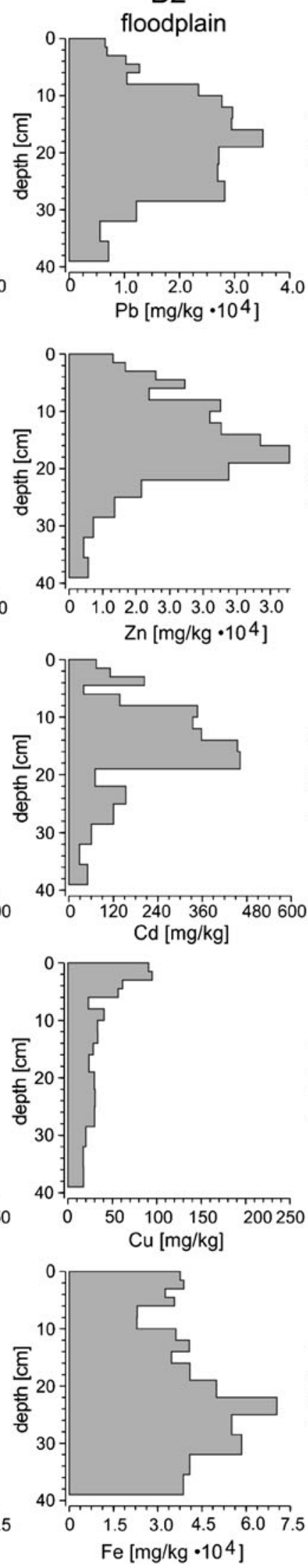

B3
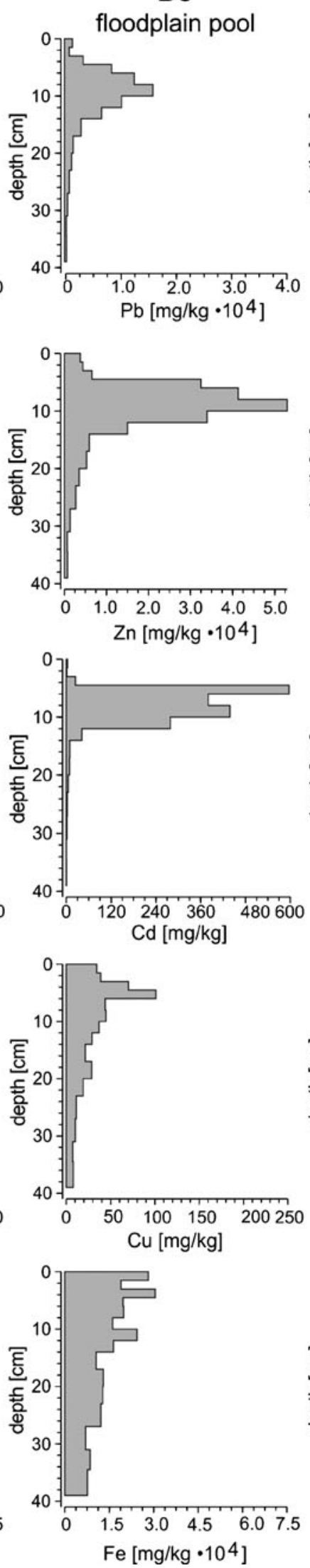

B4
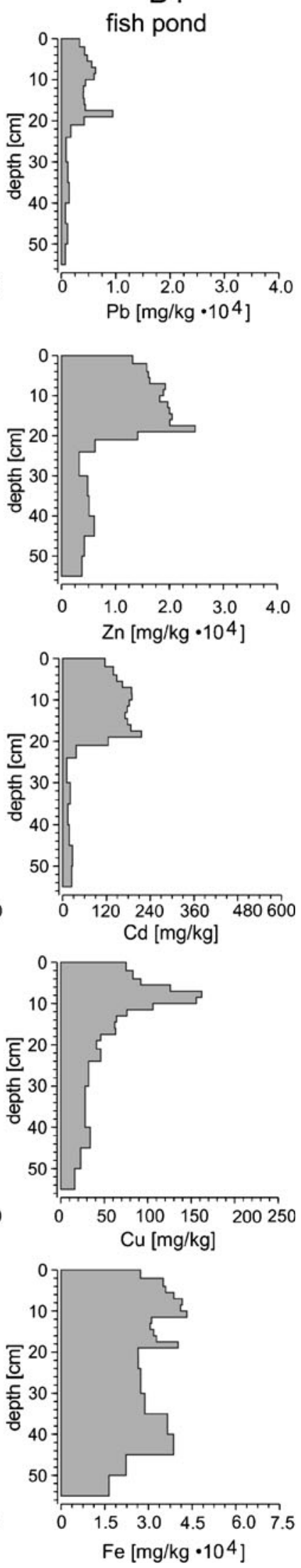

Fig. 3 Distribution of heavy metals in the vertical profiles sampled in the middle section of the Matylda catchment 
A1

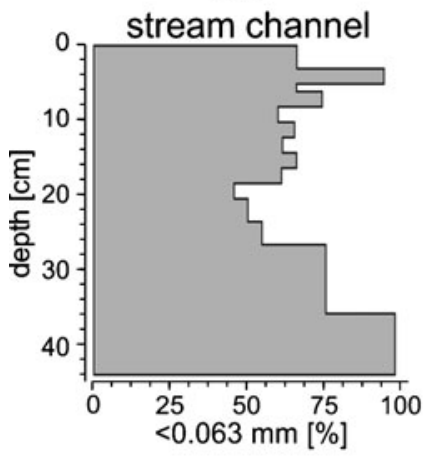

B1

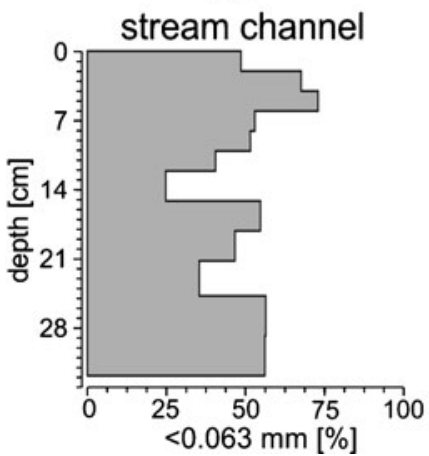

A2

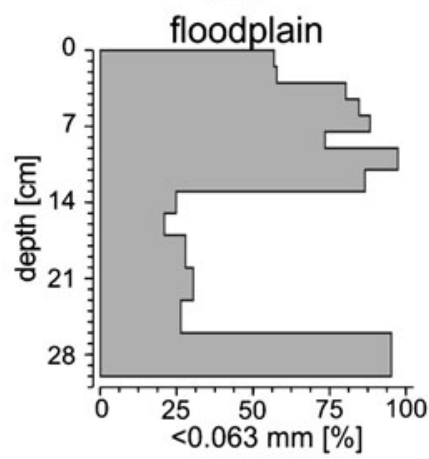

B2

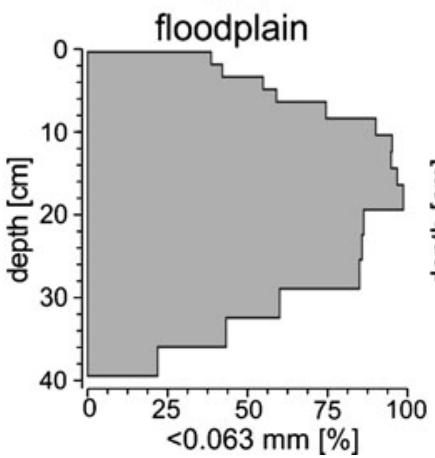

A3

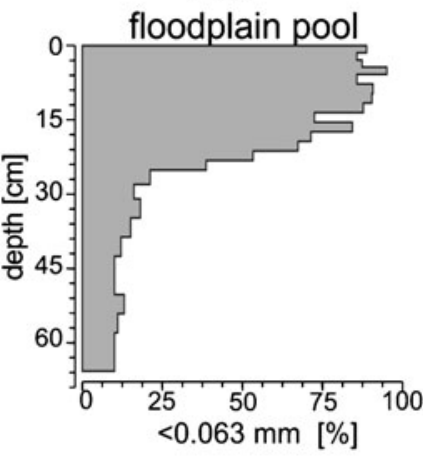

B3

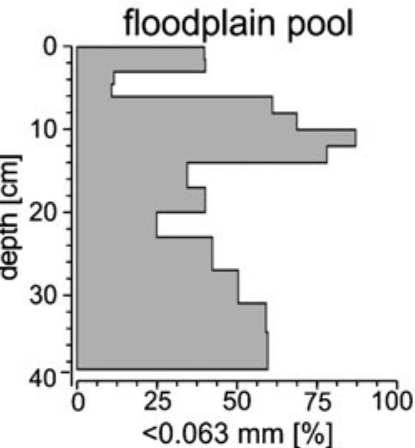

A4

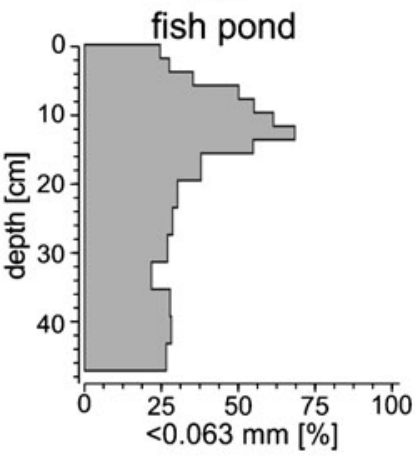

B4

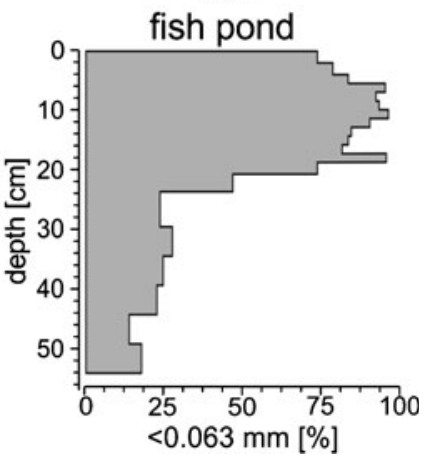

Fig. 4 Content of silt-clay fraction $(<0.063 \mathrm{~mm})$ in the sediment profiles

A1

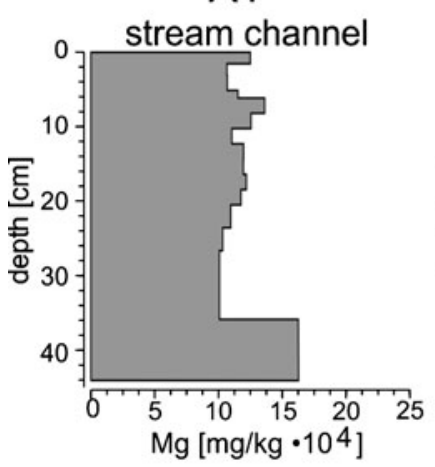

B1

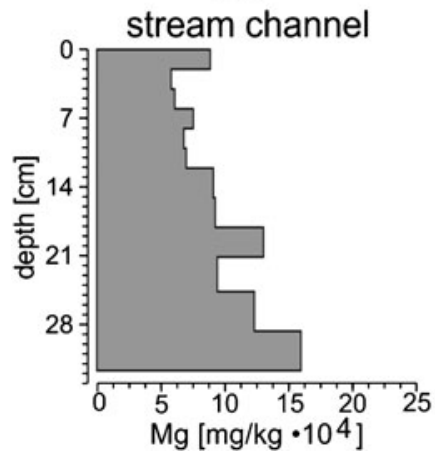

A1

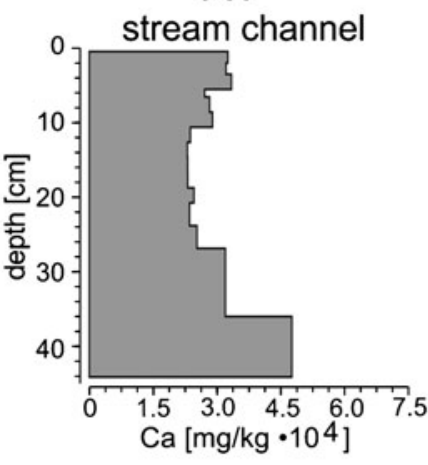

B1

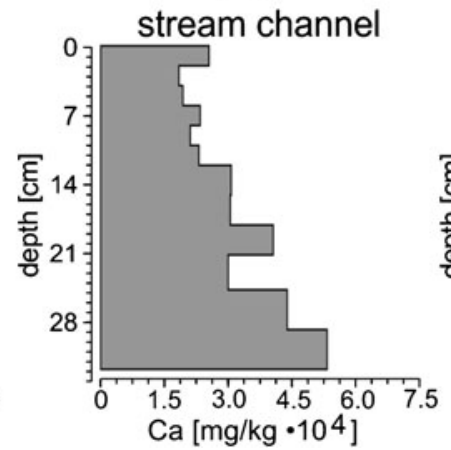

A2

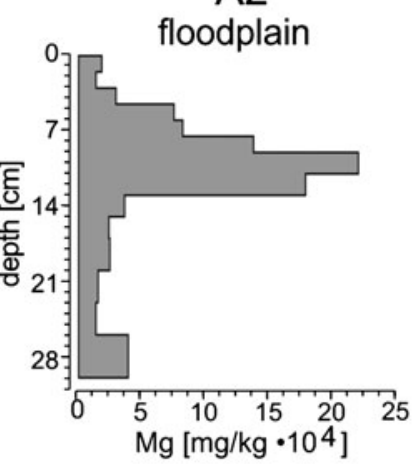

B2

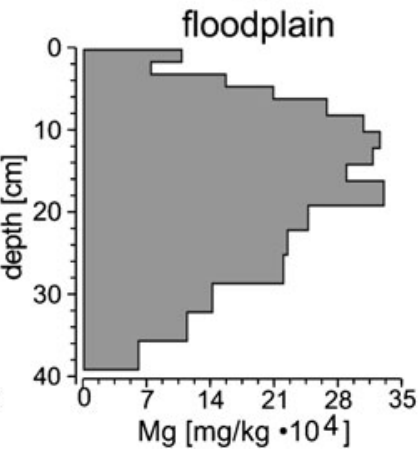

A2 floodplain

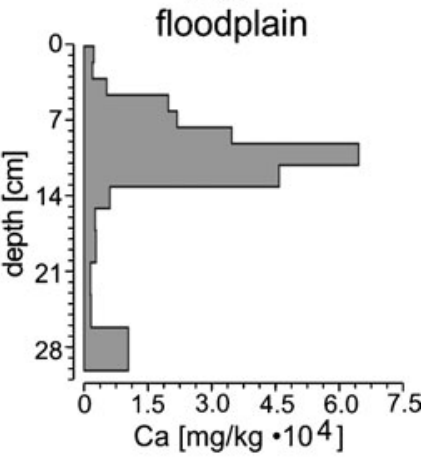

B2

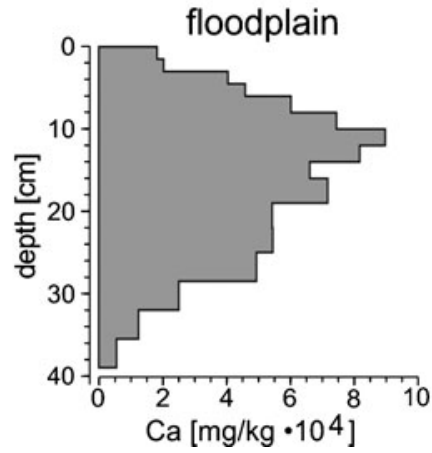

Fig. 5 Content of $\mathrm{Ca}$ and $\mathrm{Mg}$ in the stream channel and floodplain profiles 
stratigraphic units (Fig. 6). The lower $15 \mathrm{~cm}$, with $\mathrm{Fe}$ concentrations up to $60,000 \mathrm{mg} \mathrm{kg}^{-1}$, is built of coarse-grained sands, which changes towards the top into medium-grained sands. In the upper $15 \mathrm{~cm}$, there are fine-grained sandy deposits of grey colour with higher content of fine fraction. All the sediments are markedly polluted; however, the highest $\mathrm{Zn}, \mathrm{Cd}$ and $\mathrm{Pb}$ concentrations occur just over the bottom sandy layer and are similar to average maximum metal concentrations in the upstream profiles. This layer also contains high $\mathrm{Ca}$ and $\mathrm{Mg}$ contents. Gradual increase of the $\mathrm{Cu}$ content (approaching $130 \mathrm{mg} \mathrm{kg}^{-1}$ in the surface layer) is also similar to changes observed in the recent deposits of the upper Matylda reach.

\subsection{Mineralogy of vertical sediment profiles}

XRD analysis shows differences between the most and less polluted layers in sediment profiles from the channel and the floodplain of the upper and middle catchment section (Table 1). In the lower, unpolluted part of the floodplain profile A2, quartz, plagioclase and microcline grains occur, whereas in the strongly contaminated layer above, dolomite dominates over quartz with common cerrusite grains. The mineral content of the channel profile Al in the upper reach is the reverse, with the domination of dolomite over quartz in the bottom, extremely polluted layer with common smithsonite and presence of cerussite grains. The upper less polluted layer contains mainly quartz, plagioclase and feldspar with small amount of clay minerals. A similar distribution pattern was observed in the channel sediments from the middle Matylda section (B1) with dolomite grains dominating over quartz, plagioclase and cerrusite in the more polluted profile bottom. In the less polluted upper part of this profile, quartz dominates over dolomite and smectite with rare smithsonite particles. The most polluted floodplain sediments of the middle catchment (B2) are abundant in dolomite grains and contain numerous galena particles with the presence of the other heavy metal minerals: sphalerite, smithsonite and cerrusite. These minerals were not observed in the relatively weakly polluted, organic subsurface sediments.

\subsection{Heavy metal concentrations in stream bed sediments}

Concentrations of $\mathrm{Pb}, \mathrm{Zn}$ and $\mathrm{Cd}$ in the fine fraction of active streambed sediments are generally similar to the metal content in near-bank sediments at the same sampling points (Table 2). Larger differences are seen for $\mathrm{Zn}$ at sampling point M1 and at M3 with higher metal concentrations in the mid-channel. Generally, the average metal content changes downstream irregularly; however, the highest content of all elements is associated with the lowest sample at the bank overgrown with dense plant cover. $\mathrm{Cd}$ is the only element with progressive increase in average concentration over the investigated stream reach. Fe and Mn show irregular variations between sampling points; however, Mn content is always higher in the mid-channel than at the banks with the largest difference in point M3 and the presence of fine gravels in the bed. The metal content in the stream bed is lower than in surface deposits of the
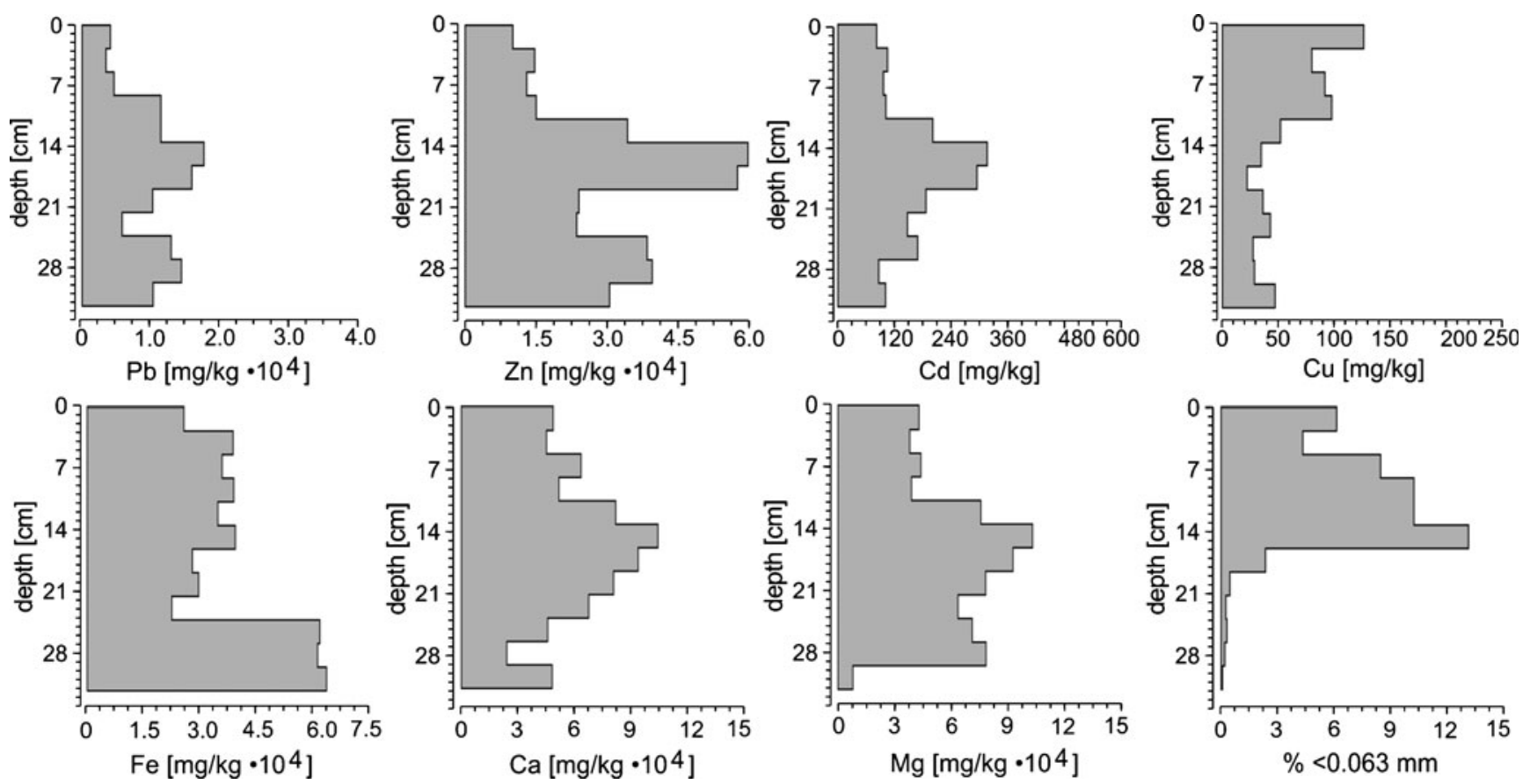

Fig. 6 Content of elements and fine fraction $(<0.063 \mathrm{~mm})$ in profile $\mathrm{C}$ of the Matylda stream sediments 
Table 1 Mineral composition of the sediment samples selected from the vertical profiles

\begin{tabular}{lllll}
\hline Profile/location & Sample depth $(\mathrm{cm})$ & Abundant & Common & Present \\
\hline A1/stream channel & $26-36$ & Quartz & Plagioclase, K-feldspar & Illite, caolinite, Ca, Mg-smectite \\
A1/stream channel & $37-44$ & Dolomite-Fe & Quartz, smithsonite & Calcite, cerussite, plagioclase \\
A2/floodplain & $9-12$ & Dolomite-Fe & Quartz, cerussite & Calcite, Ca, Mg-smectite \\
A2/floodplain & $13-15$ & Quartz & Plagioclase & Microcline \\
B1/stream channel & $8-12$ & Quartz & Dolomite-Fe, Ca, Mg- smectite & Smithsonite, plagioclase \\
B1/stream channel & $13-29$ & Dolomite-Fe & Quartz, plagioclase & Cerusite, calcite, Ca, Mg-smectite \\
B2/floodplain & $4-8$ & Dolomite-Fe & Quartz, Ca, Mg-smectite & Siderite \\
B2/floodplain & $14-22$ & Dolomite-Fe & Ca, Mg-smectite, quartz, galena & Sphalerite, smithsonite, cerusite, calcite \\
\hline
\end{tabular}

vertical profile sampled in the middle section of the Matylda (M3), whereas it is much higher than in the respective profile from the upper section (M1).

\subsection{Metal speciation in the sediments}

\subsubsection{Sediment profiles}

Sequential extraction was carried out for sediment profiles sampled from the channel (A1) and from the floodplain (B2) (see Fig. 1). In the samples analysed, $60-70 \%$ of $\mathrm{Cu}$ is associated with the organic-sulphidic fraction, except the very bottom sample from the channel with the prevalence of $\mathrm{Cu}$ in the residual fraction (Fig. 7). Only a few percent of $\mathrm{Cu}$ occurs in the acid extractable fraction. In contrast to $\mathrm{Cu}$, elements originating from the mine are generally associated with fractions that are more mobile. The largest fraction of $\mathrm{Zn}$ (average ca. $40 \%$ ) is associated with the acid extractable fraction, and in most of samples, $<20 \%$ is present in the residual fraction. $\mathrm{Cd}$, which is usually a more mobile element, is present largely in the residual fraction and oxidizable phases; however, its content varies between 20 and $90 \%$. Only about $20 \%$ of $\mathrm{Cd}$, on average, is associated with the most mobile acid extractable phase, but together with the reducible phase, they account for two thirds of $\mathrm{Cd}$ values. Generally, $50 \%$ of $\mathrm{Pb}$ occurs in the sulphidic-organic and residual fractions and only small part (ca. $<12 \%$ ) was present in the most mobile fraction. The largest fraction of $\mathrm{Pb}$ on the first level bound (50-70\%) was observed only in samples with the highest pseudo-total $\mathrm{Pb}$ content, which was about $4 \%$.

\subsubsection{Bottom sediments}

Chemical fractions were determined for sediments sampled from points M1 and M3 of the streambed. In both places, sediments represented near-bank channel bar (rich in organic matter) and the mid-channel zone (with large fine gravel content in the downstream point and fine sands in the upstream point). Similarly, to the partitioning of $\mathrm{Cu}$ in sediment profiles, $\mathrm{Cu}$ is present in all streambed samples almost exclusively in the organic-sulphidic and residual fractions (Fig. 8). Regardless of sampling place, $\mathrm{Zn}$ is present in about $40 \%$ in the most mobile fraction, which together with the reducible fraction account for $80-90 \%$. The Cd partitioning is generally similar to $\mathrm{Zn}$ with $>90 \%$ of this element present in the two most mobile phases; however, $\mathrm{Cd}$ is less evenly distributed over the various fractions than $\mathrm{Zn}$. Finally, partitioning of $\mathrm{Pb}$ suggests lower mobility than of $\mathrm{Cd}$ and $\mathrm{Zn}$ with the average $\mathrm{Pb}$

Table 2 Heavy metal concentrations, losses on ignition (LOI) and fine fraction $(<0.063 \mathrm{~mm})$ content in the sampling points M1-M4 of Matylda stream sediments

\begin{tabular}{|c|c|c|c|c|c|c|c|}
\hline \multirow[t]{2}{*}{ Parameter } & \multicolumn{2}{|l|}{ M1 } & \multicolumn{2}{|l|}{ M2 } & \multicolumn{2}{|l|}{ M3 } & \multirow{2}{*}{$\begin{array}{l}\text { M4 } \\
\text { Near-banl } \\
\text { (M4b) }\end{array}$} \\
\hline & Active channel (M1a) & Near-bank (M1b) & $\begin{array}{l}\text { Active channel } \\
\text { (M2a) }\end{array}$ & $\begin{array}{l}\text { Near-bank } \\
\text { (M2b) }\end{array}$ & $\begin{array}{l}\text { Active channel } \\
\text { (M3a) }\end{array}$ & $\begin{array}{l}\text { Near-bank } \\
\text { (M3b) }\end{array}$ & \\
\hline$<0.063 \mathrm{~mm}(\%)$ & 1.51 & 89.0 & 2.18 & 21.60 & 0.65 & 13.54 & 52.40 \\
\hline LOI $(\%)$ & 3.7 & 23.2 & 1.8 & 7.7 & 3.5 & 8.1 & 10.0 \\
\hline $\mathrm{Cd}\left(\mathrm{mg} \mathrm{kg}^{-1}\right)$ & 94.9 & 112 & 145 & 152 & 176 & 137 & 404 \\
\hline $\mathrm{Pb}\left(\mathrm{mg} \mathrm{kg}^{-1}\right)$ & 4,994 & 5,022 & 5,704 & 6,502 & 6,948 & 5,193 & 17,781 \\
\hline $\operatorname{Mn}\left(\mathrm{mg} \mathrm{kg}^{-1}\right)$ & 33,261 & 1,525 & 1,608 & 1,391 & 5,505 & 1,919 & 1,935 \\
\hline $\mathrm{Zn}(\%)$ & 3.19 & 1.96 & 2.04 & 2.04 & 2.74 & 1.79 & 4.67 \\
\hline $\mathrm{Fe}(\%)$ & 4.68 & 5.27 & 3.94 & 3.90 & 4.90 & 3.31 & 5.76 \\
\hline
\end{tabular}


Fig. 7 Speciation of $\mathrm{Cu}, \mathrm{Cd}$, $\mathrm{Pb}$ and $\mathrm{Zn}$ in vertical profiles of the channel $(A I)$ and floodplain (B2) sediments of the Matylda stream (sums of concentrations in milligrams per kilogram are given in white). Fractions: 1 acid extractable, 2 reducible, 3 oxidizable and 4 residual
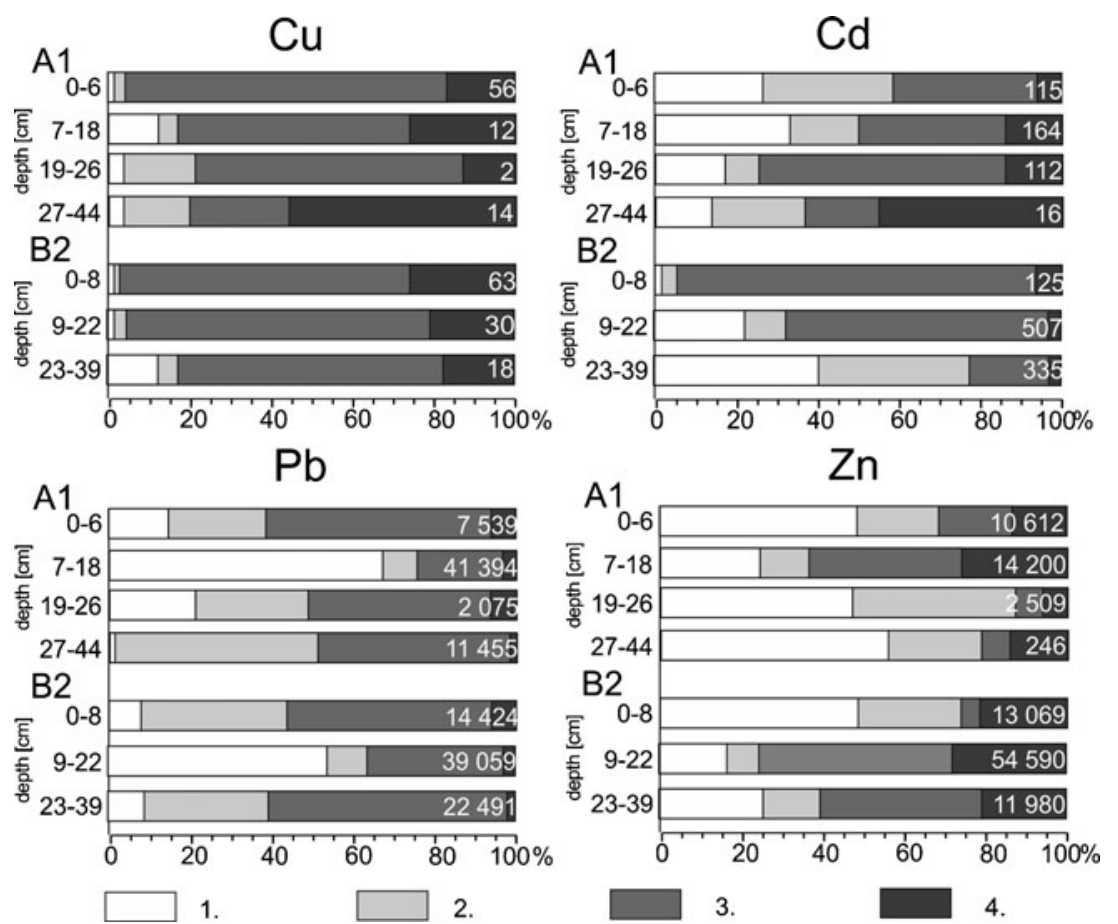

content in the acid extractable and reducible phases of about $40 \%$.

\subsection{Stream water chemistry}

Waters of the Matylda stream are alkaline in the upper reach and average $\mathrm{pH}$ drops by almost 1 unit between the last two points in the middle reach (Table 3). The concentration of most chemical compounds changes markedly with distance downstream. Sulphates decrease by about four to five times from the upper to the lowest sampling point, whereas mean concentrations of chlorides, carbonates, nitrates, calcium and magnesium decreases only by $2.5-3$ times over the same distance. Over this $4.6-\mathrm{km}$-long reach, there is a marked drop of conductance and a much smaller decrease of dissolved oxygen observed solely between the last two points. Moreover, on the same distance, there is a fourfold increase of dissolved C, particularly over the last reach.

Downstream changes of heavy metals content exhibit a more complicated dispersal pattern (Table 4). Zn concentrations drop by half over the investigated stream reach. However, the greatest change was observed between the first (M1) and the second (M2) sampling points. Mean concentrations of $\mathrm{Zn}$ decrease slowly over the rest of the stream (Fig. 9). Whereas, $\mathrm{Cu}$ shows no changes over the reach, the other elements show the opposite dispersal pattern with a more or less regular increase downstream. It is particularly evident in the cases of $\mathrm{Fe}$ and $\mathrm{Cd}$ with a fivefold increase observed. Mn content drops from the initial to the second sampling point and then it increases to the end of the
Fig. 8 Speciation of $\mathrm{Cu}, \mathrm{Cd}$, $\mathrm{Pb}$ and $\mathrm{Zn}$ in stream sediments of active channel $(1 a, 3 a)$ and near-bank zones $(1 b, 3 b)$ at M1 and M3 sampling locations. Fractions: 1 acid extractable, 2 reducible, 3 oxidizable, and 4 residual
$\mathrm{Cu}$
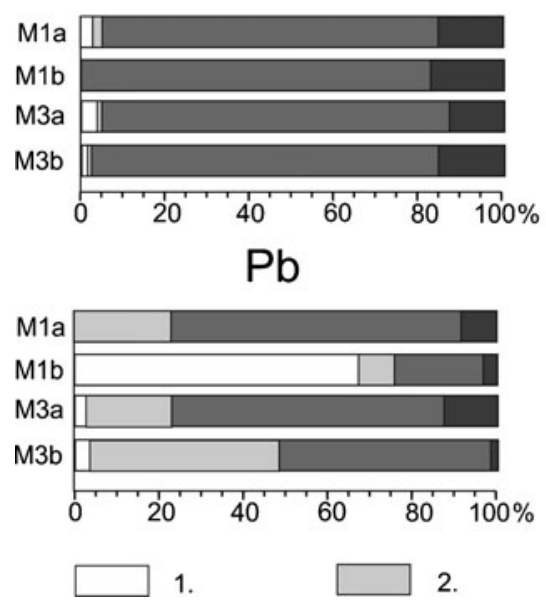
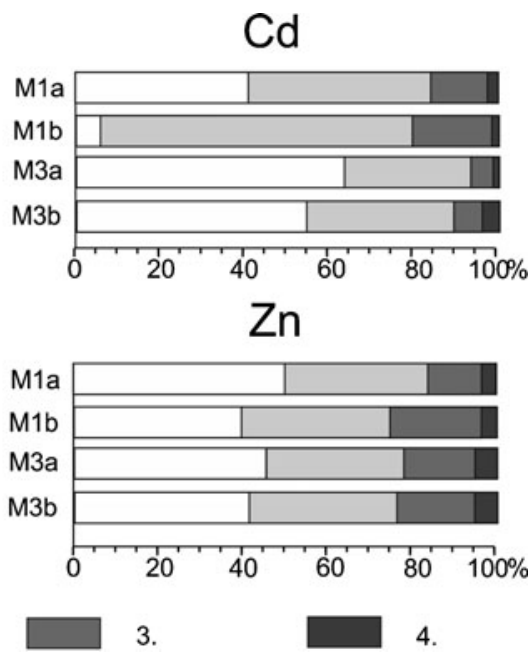
Table 3 Downstream changes (mean and standard deviation, STD) of macro-ions content (in milligrams per cubic decimetre) and conductivity (in microsiemens per centimetre) in the Matylda waters

\begin{tabular}{lllllllllll}
\hline Point & Parameter & $\mathrm{pH}$ & Conductivity & Oxygen & $\mathrm{Cl}^{-}$ & $\mathrm{CO}_{2}^{-}$ & $\mathrm{SO}_{4}^{-2}$ & $\mathrm{NO}_{3}^{-}$ & $\mathrm{Mg}$ & $\mathrm{Ca}$ \\
\hline 1 & Mean & 7.8 & 950 & 8.8 & 48.9 & 331.4 & 193.2 & 7.6 & 35.2 & 127.4 \\
& STD & 0.2 & 223 & 1.3 & 27.4 & 100.1 & 63.0 & 5.8 & 11.1 & 35.3 \\
2 & Mean & 7.9 & 661 & 8.9 & 29.1 & 226.1 & 127.4 & 5.5 & 23.6 & 93.7 \\
& STD & 0.3 & 181 & 2.0 & 4.1 & 85.0 & 50.1 & 5.2 & 12.3 & 36.7 \\
3 & Mean & 7.8 & 577 & 9.0 & 26.0 & 215.6 & 116.5 & 4.1 & 19.1 & 86.2 \\
& STD & 0.3 & 163 & 1.3 & 7.0 & 84.4 & 44.9 & 2.7 & 8.4 & 28.4 \\
4 & Mean & 7.0 & 317 & 6.8 & 18.3 & 117.0 & 44.4 & 1.8 & 9.5 & 41.4 \\
& STD & 0.5 & 78.6 & 2.1 & 3.3 & 57.7 & 20.4 & 1.3 & 2.9 & 10.2 \\
\hline
\end{tabular}

reach. Mean $\mathrm{Pb}$ concentrations increase between the M1 and M3, despite its marked drop in maximum concentrations over the entire stream reach. Whereas, seasonally most of the water parameters change irregularly over the reach, minimum $\mathrm{Cd}$ and $\mathrm{Zn}$ was observed in the 3-month dry autumn period of 2009 (Fig. 10). During the rainy early summer of 2009 and the wet winter of $2010, \mathrm{Cd}$

Table 4 Metal concentrations in waters of the Matylda stream (in milligrams per cubic decimetre)

\begin{tabular}{|c|c|c|c|c|c|}
\hline \multirow[t]{2}{*}{ Metal } & \multirow[t]{2}{*}{ Concentrations } & \multicolumn{4}{|c|}{ Matylda stream $(n=14)$} \\
\hline & & M1 & M2 & M3 & M4 \\
\hline \multirow[t]{4}{*}{$\mathrm{Cd}$} & Min & 0.0001 & 0.0002 & 0.0002 & 0.0001 \\
\hline & Max & 0.0019 & 0.0030 & 0.0040 & 0.0085 \\
\hline & Median & 0.0004 & 0.0017 & 0.0012 & 0.0024 \\
\hline & STD & 0.0005 & 0.0010 & 0.0014 & 0.0024 \\
\hline \multirow[t]{4}{*}{$\mathrm{Pb}$} & Min & 0.001 & 0.006 & 0.005 & 0.002 \\
\hline & Max & 0.069 & 0.053 & 0.050 & 0.027 \\
\hline & Median & 0.003 & 0.018 & 0.025 & 0.012 \\
\hline & STD & 0.018 & 0.013 & 0.014 & 0.008 \\
\hline \multirow[t]{4}{*}{$\mathrm{Zn}$} & Min & 0.394 & 0.216 & 0.220 & 0.039 \\
\hline & Max & 1.891 & 0.951 & 0.835 & 1.061 \\
\hline & Median & 0.982 & 0.657 & 0.620 & 0.481 \\
\hline & STD & 0.426 & 0.247 & 0.248 & 0.344 \\
\hline \multirow[t]{4}{*}{$\mathrm{Cu}$} & Min & 0.002 & 0.002 & 0.001 & 0.001 \\
\hline & Max & 0.006 & 0.004 & 0.005 & 0.005 \\
\hline & Median & 0.002 & 0.002 & 0.002 & 0.002 \\
\hline & STD & 0.002 & 0.001 & 0.001 & 0.001 \\
\hline \multirow[t]{5}{*}{$\mathrm{Mn}$} & Min & 0.071 & 0.077 & 0.073 & 0.098 \\
\hline & Max & 0.295 & 0.244 & 0.338 & 0.763 \\
\hline & Median & 0.158 & 0.113 & 0.140 & 0.149 \\
\hline & Mean & 0.165 & 0.131 & 0.148 & 0.268 \\
\hline & STD & 0.063 & 0.048 & 0.070 & 0.235 \\
\hline \multirow[t]{5}{*}{$\mathrm{Fe}$} & Min & 0.032 & 0.026 & 0.053 & 0.223 \\
\hline & Max & 0.616 & 0.361 & 0.414 & 2.961 \\
\hline & Median & 0.106 & 0.136 & 0.202 & 0.351 \\
\hline & Mean & 0.143 & 0.154 & 0.213 & 0.612 \\
\hline & STD & 0.147 & 0.096 & 0.113 & 0.714 \\
\hline
\end{tabular}

concentrations were much higher in the lower than in the upper sampling point. For $\mathrm{Zn}$, concentrations are almost always lower at M4 than at M1, but the differences are much smaller during the wet than in the dry period. Generally, considering solely physicochemical water quality parameters (including $\mathrm{Zn}$ ), stream waters are classified as third class at the first sampling point and as second class at the other points, when compared to current national fifth class water quality guidance (Dz.U. 08.162.1008). However, considering $\mathrm{Cd}$ and $\mathrm{Pb}$ content, water quality get worse downstream from the first class (very good quality) in point M1 to the third (moderate) class at points M3 or M4, whereas, Fe and Mn levels refer to the second (good) quality class and $\mathrm{Cu}$ one to the first class.

\section{Discussion}

4.1 Reconstruction of the metal dispersal in the catchment

Although this study focused on only two relative short reaches of the Matylda stream, and the results did not allow a quantification of the metal dispersal in the soils and sediments in the Matylda valley, the metal distribution in the vertical profiles sampled were consistent. The observed metal concentrations and sediment stratigraphy in the soil and sediment profiles clearly indicate the impact of mine waters discharged from the $\mathrm{Pb}-\mathrm{Zn}$ mine to the Matylda stream. In the floodplain profiles, the pre-mining period is represented by relatively unpolluted basal sediments, comprising fine-grained silty deposits. Typically, they contain less than 100, 1 and $300 \mathrm{mg} \mathrm{kg}^{-1}$ of $\mathrm{Zn}, \mathrm{Cd}$ and $\mathrm{Pb}$, respectively. Mineral composition is dominated by parent minerals of quartz with plagioclase and microcline being products of weathering fluvioglacial deposits. These sediments are overlain by a thick (up to $12 \mathrm{~cm}$ or so) organic layer containing poorly decomposed leaves, cones and twigs of black alder. Usually, the organic sediments are several times more polluted with $\mathrm{Zn}, \mathrm{Cd}$ and $\mathrm{Pb}$, probably because of dissolution and migration from the overlying contaminated deposits. 
Fig. 9 Changes of the mean $\mathrm{Cu}$, $\mathrm{Cd}, \mathrm{Pb}$ and $\mathrm{Zn}$ concentrations in waters of the Matylda stream (in milligrams per cubic decimetre) in points M1-M4 (1-4)
Cd

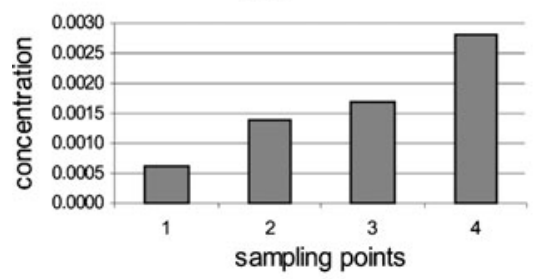

$\mathrm{Pb}$

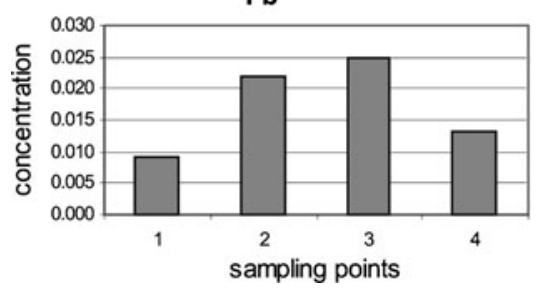

Zn

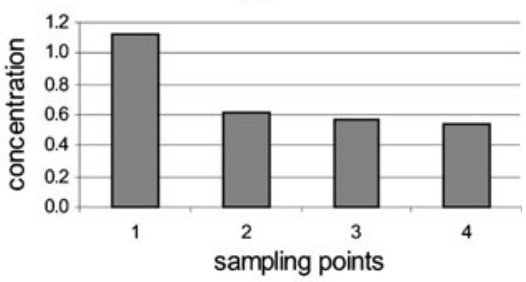

Cu

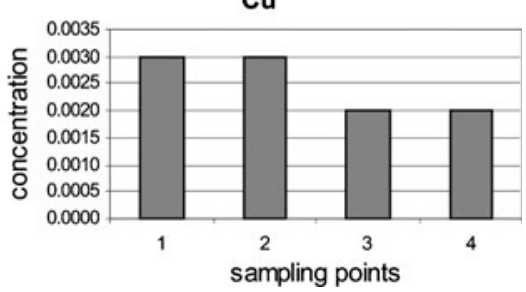

In almost all floodplain and fishpond profiles, the increase of $\mathrm{Zn}, \mathrm{Cd}$ and $\mathrm{Pb}$ content in the overlying layer is sharp and parallel to the change in sediment stratigraphy. This layer consists mainly of clays and silts, which are yellow to brown in colour depending on the thickness and organic matter content. The deposition of these fine-grained sediments was rapid enough to slow down degradation of organic matter in the lower layer due to limiting access to oxygen. Several centimetres thick transition zones, with slower increases in metal content (e.g. in B2 profile), are probably related to the variable density of clays and organic matter, leading to sinking of the upper and dense clay layer. The very fine-grained layer is the most polluted with $\mathrm{Zn}$ and $\mathrm{Pb}$ contents $>30,000 \mathrm{mg} \mathrm{kg}^{-1}$ and $\mathrm{Cd}>300 \mathrm{mg} \mathrm{kg}^{-1}$. In this layer, there are also maximum $\mathrm{Ca}$ and $\mathrm{Mg}$ concentrations, which are similar to those in the excavated ore, which indicate that the mine is the origin. Moreover, the sediments are characterised by domination of dolomites over quartz and the presence of grains of the excavated ore, mainly secondary ore minerals of cerrusite and smithsonite and generally less frequent grains of primary sulphide minerals of galena and sphalerite. It is evident that the metals were accumulated on the floodplain during longer periods of inundation by mine waters, which transported metals and very fine dolomite particles in suspension. Presently, mine waters from a $\mathrm{Pb}-\mathrm{Zn}$ mine, probably of a similar quality, are still discharged to the neighbouring Biała Przemsza catchment causing permanent high levels of river water turbidity (average suspended matter content about $80 \mathrm{mg} \mathrm{dm}^{-3}$ ) and high levels of sediment metal pollution. The Stoła River (Biała Przemsza tributary) also receives similar quantity of mine waters amounting to $1 \mathrm{~m}^{3} \mathrm{~s}^{-1}$ and transports annually about $500 \mathrm{t}$ of suspended matter, $40 \mathrm{t}$ of $\mathrm{Zn}, 6 \mathrm{t}$ of $\mathrm{Pb}$ and $200 \mathrm{~kg}$ of $\mathrm{Cd}$ (Ciszewski 1998). It is also possible that, during several periods of the mine extension, the suspended load in discharged waters could be several times higher. The top of this layer in the floodplain profiles is well-defined by a decrease in concentrations of mine-originated heavy metals and the rapid rise of LOI content. The thickness of this layer is variable and depends on floodplain height and topography. The greatest thickness, in the order of dozen or so centimetres, is related to low levels and unconfined floodplain locations several tens of metres wide, whereas, this layer is only several centimetres thick in floodplain pools and is limited by artificial dykes or the other obstacles like dense plant cover. This layer probably accumulated for almost the entire period of mine functioning. Accumulation probably took place since the beginning as initially mine waters were discharged directly to the stream channel, which was of relatively small capacity. Channelization of the stream in the 1920s and 1950s did not eliminate
Fig. 10 Changes of $\mathrm{Cd}$ and $\mathrm{Zn}$ concentrations (in milligrams per cubic decimetre) in the investigated period in the upper (MI) and the lowest (M4) sampling points on the Matylda Stream
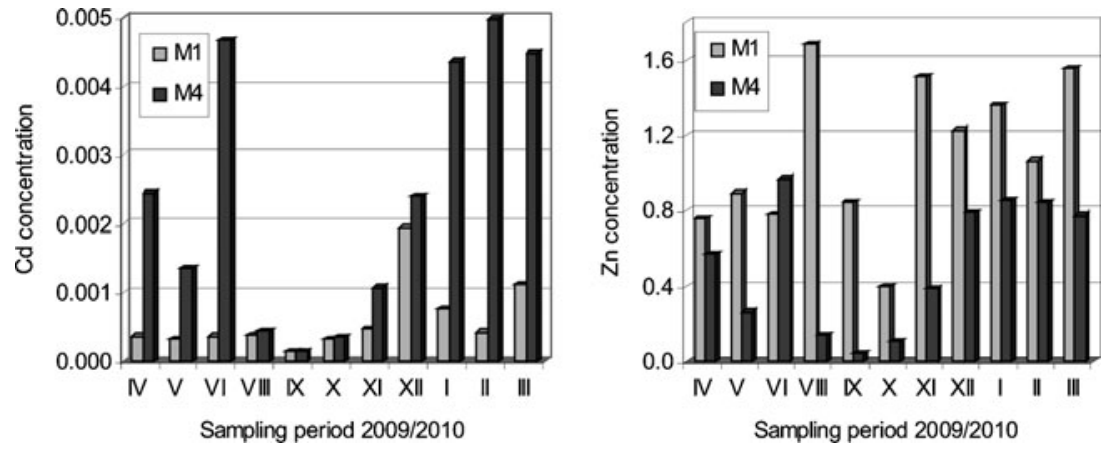
inundation of the low-slope reaches due to construction of low dykes from permeable sands and constant fishponds supplied with mine waters. It resulted in creation of obstacles for draining the valley bottom and the appearance of numerous permanent floodplain pools. They were a sink of metal-polluted sediments; however, it is not clear to what extent relatively lower deposition in pools is related to obstacles for direct flow of stream waters on the floodplain and whether it results from shorter deposition period. Since the closure of the mine, the mine-originated layer, unevenly distributed over the valley bottom, became the principal source of contamination of waters, the most recent sediments and plants within the Matylda catchment with $\mathrm{Zn}, \mathrm{Cd}$ and $\mathrm{Pb}$.

Both profiles from the Matylda channel (A1, B1) represent a period which started after the mine closure because halting of drainage from the mine markedly diminished the discharge of the Matylda stream and enabled the deposition of fine sediments in the channel. Accumulation of sediments caused the formation of the low alluvial level and channel narrowing (in B1) or sediment accretion and channel shallowing (in A1). Probably, the bottom of the profile, which rests on channel gravels (B1), represents a period immediately after the mine closure. It is confirmed by mineral composition dominated by dolomites and numerous heavy metal minerals, which originated from channel erosion of the upper reach; however, the presence of plagioclase could indicate the erosion of parent minerals as a second sediment source. Nevertheless, the very high concentrations of $\mathrm{Zn}, \mathrm{Cd}$ and $\mathrm{Pb}$, similar to those observed in the most polluted layer, indicate reworking of the mine-originated sediments, which dominated the first phase after mine closure. The same process is reflected in the bottom sediments of the side Matylda channel with the highest metal concentrations in medium grain-sized sands. The sandy silts of the channel profile represent the next phase of the catchment recovery from the middle reach, overlying the bottom layer. Lack of heavy metal minerals and predomination of quartz and plagioclase suggests that most of mine-originating minerals had been removed from the active channel due to erosion. Again, almost only weathered catchment minerals were transported downstream.

The relatively short period of decrease of the sediment pollution is followed by a longer period with a constant pollution plume transferred down the catchment. It is expressed in metal concentrations which vary throughout profiles between 10,000 and $15,000 \mathrm{mg} \mathrm{kg}^{-1}$ for $\mathrm{Zn}$ and $\mathrm{Pb}$ and $100-120 \mathrm{mg} \mathrm{kg}^{-1}$ for $\mathrm{Cd}$ and reflect content of these metals in suspended matter, consisting largely of products of organic matter degradation, entrapped in the channel and fishponds. Domination of organic matter in the recently accumulated sediments is indicated by the very high LOI, which exceed $50 \%$ but reaches $80 \%$ in many samples. This period is also identified in profiles by pollution with $\mathrm{Cu}$, which is probably related to discharge of sewages from an asphalt plants operating in Chrzanów since 1980s. The whole post-mining period is represented by the profile from the upper fishpond, of which the lower part consists of sandy silts. Due to its low pollution, it may be identified as the former bottom of the pond, formed in 1974. In contrast, high pollution of organic sediments in the top 16$\mathrm{cm}$-thick layer seems to be related to metal sorption processes by organic matter and eventually by $\mathrm{Fe}$ and $\mathrm{Mn}$ hydroxides, rather than to physical deposition of polluted sediments from the catchment because a low dike separates the sampled section of the pond and precludes direct flow of water. Similar metal concentrations and distributions are observed in the fishpond of the middle reach (profile A4) suggesting, by analogy, a similar age of the upper polluted sediments and domination of metals associated with organic matter and hydroxides.

It is also worth noting the difference between metal distributions in the top of the profiles from the floodplain and the rest of profiles. In particular, floodplain pools exhibit the lowest recent metal concentrations and the lowest sediment accretion rate equal to $2-5 \mathrm{~cm}$ during the last 40 years, considering the depth of the largest decrease of the metal content at the surface. It gives the average annual accretion rate of the order of $0.5-1 \mathrm{~mm}^{-1} \mathrm{year}^{-1}$ and is related solely to autochthonous organic matter decomposition. This rate is about two times higher, with also two to three times higher metal concentrations on the floodplain because sediments are supplied seasonally from the channel. Whereas, the rate of sediment deposition in the channel reaches about $1 \mathrm{~cm}$ yeat ${ }^{-1}$ and metal concentrations are of the same order as on the floodplain. Intermediate rates of sediment accumulation, about $0.5 \mathrm{~cm}$ year $^{-1}$, are characteristic for the fishpond profiles, which are relatively high considering degradation of in situ organic matter as the dominant source and is explained by the high productivity of the near-bank ecosystem, with reeds as the main plant species.

\subsection{Factors controlling contemporary metal dispersal in the catchment}

Generally, the content of $\mathrm{Zn}, \mathrm{Cd}$ and $\mathrm{Pb}$ in sediments of the post-mining era is about three to five times lower than in the mine-originated layer both in the channel and floodplain profiles. This indicates the important role of metal dissolution and readsorption processes, which control metal redistribution in the catchment. Lowering of metal concentrations in the surface sediments is related primarily to the rapid production of organic matter. On the floodplain, it is related to the decomposition of alder leaves because the entire floodplain is overgrown with dense alder forest. Composite sample of several tens of alder leaves collected in the area of profile location in the upper reach (A) showed 
low content equal to $182,0.76$ and $110 \mathrm{mg} \mathrm{kg}^{-1}$ for $\mathrm{Zn}$, $\mathrm{Cd}$ and $\mathrm{Pb}$, respectively, indicating the small metal uptake by this tree species. Concentrations of $\mathrm{Zn}, \mathrm{Cd}$ and $\mathrm{Pb}$ in the analogous sample from the middle (B) reach (447, 1.36 and $19 \mathrm{mg} \mathrm{kg}^{-1}$, respectively) were slightly higher than in the upper reach. The values differ only a little from $\mathrm{Zn}\left(158 \mathrm{mg} \mathrm{kg} \mathrm{kg}^{-1}\right), \mathrm{Cd}$ $\left(0.67 \mathrm{mg} \mathrm{kg}^{-1}\right)$ and $\mathrm{Pb}$ (below detection limit) contents in the reference sample collected outside the valley bottom. Small foliar concentrations, particularly if compared to the very high metal content in the soil, are typical for black alders also growing on other polluted sites (Mertens et al. 2004). It may result from numerous factors like low bioavailability in soil, poor translocation from roots to shoots or physiological mechanisms, e.g. sequestration of metals by mycorrhizal fungi (Pulford and Watson 2003). Nevertheless, abundant leaf fall creates the main substrate for organic matter production on the floodplain, affecting metal mobility and availability. It is suspected, however, that depending on the type of litter composition, it initially induces increases of metal concentrations, which may be exported from the flooded soil in the period followed by metal readsorption (Du Laing et al. 2008).

Organic matter degradation is a process consuming much of the soil oxygen leading to reducible or strongly reducible conditions, which are permanent in submerged soils with low degradation rates (Sahrawat 2003). This explains the thick organic sediments observed particularly in fishponds, as well as the poorly degraded organic matter on larger depths in profiles from floodplain pools. The anoxic conditions occur at the top of these submerged profiles and their Eh values generally decrease from about -60 to $-70 \mathrm{mV}$ in the surface $10 \mathrm{~cm}$ to -120 to $-180 \mathrm{mV}$ at a depth of 10 $20 \mathrm{~cm}$. Waterlogged and anoxic conditions, which seasonally occur on the floodplain, may inhibit metal mobility through coprecipitation with sulphides and subsequent sequestration in the soil, as long as reducing conditions are maintained (Bourg and Loch 1995). This is usually confirmed by the metal speciation, with the presence of metals largely in the oxidizable phase, which is characteristic for wetland sediments ( $\mathrm{Bi}$ et al. 2007). In the present study, most $\mathrm{Cu}$ and about $50 \%$ (on average) of $\mathrm{Pb}, \mathrm{Cd}$ and $\mathrm{Zn}$ are associated with oxidisable and residual phases suggesting their low mobility, controlled here to a large extent by presence of carbonates. However, this study suggests a higher mobility of $\mathrm{Zn}$, at least in some layers, which occurs in the exchangeable fraction. It is particularly important, considering not only high $\mathrm{Zn}$ but also $\mathrm{Cd}$ contents, because even $10,000 \mathrm{mg} \mathrm{kg}^{-1}$ of $\mathrm{Zn}$ and $>100 \mathrm{mg} \mathrm{kg}^{-1}$ of $\mathrm{Cd}$ are only weakly associated with the sediments. Higher mobility of these metals in some layers could be related to plant roots, which were sparsely distributed in the sediment profiles. The phenomenon of oxygen transport by living roots, reversing the accumulation of reduced sulphides eventually affecting $\mathrm{Zn}$ mobility, was found also in the other studies on wetland sediments (Jacob and Otte 2004). Generally, the role of organic matter being a medium controlling redox potential and effectively scavenging metals from solutions seems to be more important than variability of waterlogging because there is not a marked difference between metal associations in the stream channel, channel bed and floodplain.

Extraction of the ore-bearing dolomites resulted in the presence of calcium carbonates in deposits of the mining era and their abundance in the post-mining stream sediments. Moreover, continuous draining of the dolomite water body by the Matylda results in an alkaline $\mathrm{pH}$ of stream waters in the study reach, as is evident from an average $\mathrm{pH}$ of 7.8 and raised content of $\mathrm{Ca}$ and carbonates, which decreases between the first and the last sampling points. The high and relatively constant $\mathrm{pH}$ is among the most important factors limiting dissolution of heavy metals (KabataPendias and Pendias 1992). In fact, regions of metal mining involving carbonate rocks have relatively low concentrations of heavy metals in draining waters and relatively good buffering properties preventing dispersion of pollutants in solution (Zabowski et al. 2001; Yang et al. 2006; Navarro et al. 2008). Nevertheless, in the present study, low $\mathrm{Cd}$ concentrations in the first sampling point gradually increase about five times over the short study reach indicating leaching of sediments stored both on the floodplain and in the stream. This leaching is much more intensive during period of higher rainfall and snow melt than during dry period and may be related to a large flux of shallow groundwaters to the stream (Alekasander-Kwaterczak and Ciszewski 2012). This effect was not observed for $\mathrm{Zn}$ because of sewage discharge from Chrzanów City and markedly raised Zn content at the first sampling point. Pd concentrations increased much less over the same reach probably because of generally lower $\mathrm{Pb}$ solubility.

Generally, metal concentrations in stream waters are not proportionally low compared to extreme values of metal concentrations in the sediments accumulated over the valley bottom in the upper part of the catchment. This results from the thin layer of the mine-originated sediment, which is unevenly distributed over the valley bottom. Sections of the sediments lying on the banks are not inundated due to stream channelization or are inundated only seasonally, which shorten the potential time for metal leaching and results in low metal concentrations in ground waters (Aleksander-Kwaterczak and Ciszewski 2012). Perhaps, the more important reason for the low rate of metal mobilisation is the small volume of water (of the order of few $\mathrm{dm}^{3} \mathrm{~s}^{-1}$ ) draining the entire catchment. Moreover, storage of these sediments in permanently anoxic conditions and leaching by the alkaline water favour metal stabilisation 
and hamper metal transfers downstream. It seems that most metals mobilised from the polluted layer are trapped in the overlying organic sediment with concentrations which are similar at the surface over the entire catchment and are remobilized due to slow organic matter degradation. There is also slow sediment erosion, confined to the channel, and expressed by the very high metal content, which is typical for small catchments in old mining areas (Byrne et al. 2010).

\subsection{Catchment rehabilitation strategy}

Rehabilitation of mine sites including waste heaps, bare contaminated soils and acid mine waters draining abandoned adits are successfully conducted using numerous approaches widely described in the literature (e.g. Mulligan et al. 2001). However, the greatest rehabilitation problems arise when metal contaminants released from mining and processing operations enter river systems. It results in longterm contamination of bed and floodplain sediments also affecting water quality over long distances. In such cases, the dispersal of metal contaminants in river systems governed by fluvial geomorphic processes and standard remediation procedures must be enhanced by geomorphologically based assessments (Macklin et al. 2006). In this study, the dispersal of metal contaminants is spatially variable due to variable valley floor morphology (which also controls the frequency and duration of inundation), the rate of organic matter degradation and the leaching of heavy metals. Metal mobilisation from the catchment, although a slow process as indicated by the present and earlier studies (AleksanderKwaterczak and Ciszewski 2012), has been not properly estimated before rehabilitation of the mine site was undertaken. It results in persistent water contamination with heavy metals, which seems to affect the structure and composition of plankton communities (Wilk-Woźniak et al. 2011). There are also other examples when costly remediation of mine sites was not successful because of further leaching of metal pollutants remaining in the downstream system (Taylor 2007) or when a post-rehabilitation audit showed an ongoing environmental hazard because of exposure of mine-originated sediments in the newly formed channel (Gore et al. 2007). These experiences suggest that great care will be required in any attempt to rehabilitate the Matylda catchment, particularly because the mine-originating, polluted layer is relatively thin and may be dispersed over a large part of the valley bottom. Mechanical removal of the surface layer would destroy the floodplain forest and expose the sediments to atmospheric oxygen. Outcropping of bare soils, even if planted, could increase leaching of reworked wastes and the input of dissolved metals, particularly to the receiving fishponds, a phenomenon also observed in the similar minecontaminated catchment of the Nant-y-Fendrod stream in Wales (Blake et al. 2007). In the present study, we would recommend not disturbing the material in the first place, as this would be the most cost-efficient option designed for anoxic inland waterways (Baldwin and Fraser 2009). This option prevents oxidation of reduced sediments by maintaining high water level at no costs. Fortunately, the fishponds are poorly managed by local anglers community who introduce fish to the ponds several times each year, and most of the fish are caught within less than a month. The ponds are constantly filled with water, also controlling the high water level in the adjacent polluted wetlands and in the upper and middle Matylda floodplain. Moreover, the present study shows that dredging of contaminated sediments from fishponds, which are fed with groundwaters and surface waters from Matylda, would not be successful over the long term because of constant leaching of contaminated sediments dispersed over the valley bottom.

\section{Conclusions}

Observed changes in metal concentrations and sediment stratigraphy in profiles sampled in floodplain, stream channels and fishponds suggest rapid downstream changes in metal loads in the Matylda stream during the 100-year operation of the Matylda $\mathrm{Pb}-\mathrm{Zn}$ mine and after its closure in 1972. Fine-grained sediments containing ore-bearing dolomites, sphalerite, galena, cerrusite and smithsonite were transported with mine waters and accumulated in a polluted layer over the inundated valley bottom. This layer of up to $12 \mathrm{~cm}$ or so thick, with $\mathrm{Zn}$ and $\mathrm{Pb}$ concentrations of several percent and Cd concentrations of $300-600 \mathrm{mg} \mathrm{kg}^{-1}$ is, after mine site rehabilitation, the principal source of these heavy metals for downstream reaches with fishponds. Closure of the mine was followed by a relatively short period of rapid redistribution of sediment-associated heavy metals in the stream channel. Since the 1980 s, the floodplain and fishponds have received constant amounts of metals as suggested by uniform, lower (by three to five times) metal concentrations in recent deposits up to $20 \mathrm{~cm}$ thick. It contrasts with rapid decrease of metal concentrations in floodplain pools and slow sediment accretion rate related to dilution by decomposed leaf litter. A fivefold increase of Cd content over the 4-km study reach of the Matylda stream, and the small portion of this element in the residual phase, indicates continuous leaching of this element from the polluted layer. Nevertheless, the content of $\mathrm{Cd}, \mathrm{Zn}$ and $\mathrm{Pb}$ in stream waters is relatively low and results from relatively small thickness of mine-originated sediment layer, the widespread anoxic conditions in the most recent sediments and the slightly alkaline $\mathrm{pH}$ of stream water, which reduces metal mobility. Distribution of the contaminated layer over the large area of the valley bottom precludes cost-efficient catchment rehabilitation. The only effective, but expensive, 
remediation measure would be the dredging of contaminated sediment from fishponds and the subsequent storage of this sediment in a confined area.

Acknowledgments This work was funded by the Ministry of Science and Higher Education grant no. N N305 232735.

Open Access This article is distributed under the terms of the Creative Commons Attribution License which permits any use, distribution, and reproduction in any medium, provided the original author(s) and the source are credited.

\section{References}

Aleksander-Kwaterczak U, Ciszewski D (2012) Groundwater hydrochemistry and soil pollution in a catchment affected by an abandoned lead-zinc mine: functioning of a diffuse pollution source. Environ Earth Sci 65(4):1179-1189

Aleksander-Kwaterczak U, Helios-Rybicka E (2009) Contaminated sediments as a potential source of $\mathrm{Zn}, \mathrm{Pb}$ and $\mathrm{Cd}$ for a river system in the historical metalliferous ore mining and smelting industry area of south Poland. J Soils Sediment 9:13-22

Baldwin DS, Fraser M (2009) Rehabilitation options for inland waterways impacted by sulfidic sediments - a synthesis. J Environ Manage 91:311-319

Bi X, Feng X, Yang Y, Li X, Sin GPY, Qiu G, Qian X, Li F, He T, Li P, Liu T, Fu Z (2007) Heavy metals in an impacted wetland system: a typical case from southwestern China. Sci Total Environ 387:257-268

Blake WH, Walsh RPD, Barnsley MJ, Smith J (2007) Impacts of landscape remediation on the heavy metal pollution dynamics of a lake surrounded by non-ferrous smelter waste. Environ Pollut 148:268-280

Bourg ACM, Loch JPG (1995) Mobilization of heavy metals as affected by $\mathrm{pH}$ and redox conditions. In: Salomons W, Stigliani WM (eds) Biogeodynamics of pollutants in soils and sediments. Springer, Berlin, pp 87-102

Byrne P, Reid I, Wood PJ (2010) Sediment geochemistry of streams draining abandoned lead/zinc mines in central Wales: the Afon Twymyn. J Soils Sediment 10:683-697

Cappuyns V, Swennen R (2004) Secondary mobilization of heavy metals in overbank sediments. J Environ Monit 6:434-440

Ciszewski D (1998) Channel processes as a factor controlling accumulation of heavy metals in river bottom sediments: consequences for pollution monitoring (upper Silesia, Poland). Environ Geol 36:45-54

Ciszewski D, Czajka A, Błażej S (2008) Rapid migration of heavy metals and ${ }^{137} \mathrm{Cs}$ in alluvial deposits, Upper Odra River valley, Poland. Environ Geol 55:1577-1586

Dennis IA, Coulthard TJ, Brewer P, Macklin M (2009) The role of floodplains in attenuating contaminated sediment fluxes in formerly mined drainage basins. Earth Surf Proc and Land 34:453-466

Du Laing G, Bontinck A, Samson R, Vandecasteele B, Vanthuyne DRJ, Meers E, Lesage E, Tack FMG, Verloo MG (2008) Effect of decomposing litter on the mobility and availability of metals in the soil of a recently created floodplain. Geoderma 147:34-46

Dz.U. 08.162.1008 at: http://geoportal.pgi.gov.pl/css/powiaty/prawo/ Dz.U.08.162.1008 (in Polish)

Gore DB, Preston NJ, Fryirs KA (2007) Post-rehabilitation environmental hazard of $\mathrm{Cu}, \mathrm{Zn}, \mathrm{As}$ and $\mathrm{Pb}$ at the derelict Conrad Mine, eastern Australia. Environ Pollut 148:491-500
Górecka E, Leach DL, Kozłowski A (1996) Carbonate-hosted zinc and lead deposits in the Silesian-Cracow area, Poland. PIG Prace $154: 2-182$

Harrison J, Hijnis H, Caprarelli G (2003) Historical pollution variability from abandoned mine sites, Greater Blue Mountains World Heritage Area, New South Wales, Australia. Environ Geol 43:680-687

Hudson-Edwards KA, Macklin MG, Curtis CD, Vaughan DJ (1998) Chemical remobilization of contaminated metals within sediments in an incising river system: implications for dating and chemostratigraphy. Earth Surf Proc Landf 23:671-684

Jacob DL, Otte ML (2004) Long-term effects of submergence and wetland vegetation on metals in a 90 -year old abandoned $\mathrm{Pb}-\mathrm{Zn}$ mine tailings pond. Environ Pollut 130:337-345

Kabata-Pendias A, Pendias H (1992) Trace elements in soils and plants. CRC, Boca Raton, p 365

Kraus U, Wiegand J (2006) Long-term effects of the Aznallcollar mine spill-heavy metal content and mobility in soils and sediments of the Guadiamar River valley (SW Spain). Sci Total Environ 367:855-871

Lee JY, Choi JC, Lee KK (2005) Variations in heavy metal contamination of stream water and groundwater affected by an abandoned lead-zinc mine in Korea. Environ Geochem Health 27:237-257

Lintnerova O, Sotnik P, Soltes S (2008) Abandoned Smolnik Mine (Slovakia) - a catchment area affected by mining activities. Est J Earth Sci 57:104-110

Macklin MG, Brewer PA, Hudson-Edwards KA, Bird G, Coulthard TJ, Dennis IA, Lechler PJ, Miller JR, Turner JN (2006) A geomorphological approach to the management of rivers contaminated by metal mining. Geomorphology 79:423-447

Marquez MJ, Martinez-Conde E, Rovita JV, Ordonez S (2001) Heavy metals pollution of aquatic ecosystems in the vicinity of a recently closed underground lead-zinc mine (Basque Country, Spain). Environ Geol 40:1125-1137

Mertens J, Vervaeke P, De Schrijver A, Luyssaert S (2004) Metal uptake by young trees from dredged brackish sediment: limitations and possibilities for phytoextraction and phytostabilisation. Sci Total Environ 326:209-215

Mighanetara K, Braungardt CB, Rieuwerts JS, Azizi F (2009) Contaminant fluxes from point and diffuse sources from abandoned mines in the River Tamar catchment, UK. J Geochem Explor 100:116-124

Miller JR (1997) The role of fluvial geomorphic processes in the dispersal of heavy metals from mine sites. J Geochem Explor 58:101-118

Mulligan CN, Yong RN, Gibbs BF (2001) Remediation technologies for metal-contaminated soils and groundwater: an evaluation. Eng Geol 60:193-207

Navarro MC, Perez-Sirvent C, Martinez-Sanches MJ, Vidal J, Tovar PJ, Bech J (2008) Abandoned mine sites as a source of contamination by heavy metals: a case study in a semi-arid zone. J Geochem Explor 96:183-193

Owens PN, Walling DE (2003) Temporal changes in the metal and phosphorus content of suspended sediment transported by Yorkshire rivers, U.K. over the last 100 years, as recorded by overbank floodplain deposits. Hydrobiologia 494:185-191

Pasieczna A (2008) Detailed geochemical map of Upper Silesia, Chrzanów sheet 1:25000. Państwowy Instytut Geologiczny (State Geological Survey), Warszawa

PN-EN ISO 17294-1:2007 at: http://www.khgi.agh.edu.pl/i/pdf/ ibok-ab1050/ab1050.pdf\&nbsp;\&nbsp

Pulford ID, Watson C (2003) Phytoremediation of heavy metalcontaminated land by trees: a review. Environ Int 29:529-540

Pulford ID, Mackenzie AB, Donatello S, Hastings L (2008) Source term characterization using concentration trends and geochemical 
associations of $\mathrm{Pb}$ and $\mathrm{Zn}$ in river sediments in the vicinity of a disused mine site: implications for contaminant metal dispersion processes. Environ Pollut 157:1649-1656

Rauret G, López-Sánduz JF, Sahuquillo A (1999) Improvement of the BCR three-step sequential extraction procedure prior the certification of new sediment and soil reference materials. J Environ Monit 1:57-61

Rodriguez L, Ruiz E, Alonso-Azcarate J, Rincon J (2009) Heavy metal distribution and chemical speciation in tailings and soils around a $\mathrm{Pb}-\mathrm{Zn}$ mine in Spain. J Environ Manag 90:1106-1116

Sahrawat KL (2003) Organic matter accumulation in submerged soils. Adv Agron 81:169-201

Szuwarzyński M (2000) Zakłady Górnicze "Trzebionka" S.A. 19502000. Wyd. Przedsiębiorstwo Doradztwa Technicznego "Kadra", Trzebinia

Taylor MP (2007) Distribution and storage of sediment-associated heavy metals downstream of the remediated Rum Jungle Mine on the East Branch of the Finniss River, Northern Territory, Australia. J Geochem Explor 92:55-72

Walling DE, Owens PN, Leeks GL (1998) The role of channel and floodplain storage in suspended sediment budget of the River Ouse, Yorkshire, UK. Geomorphology 22:225-242

Wilk-Woźniak E, Pociecha A, Ciszewski D, Aleksander-Kwaterczak U, Walusiak E (2011) Phyto- and zooplankton in fishponds contaminated with heavy metal runoff from a lead-zinc mine. Oceanol Hydrobiol Studies 40:77-85

Yang YG, Liu CQ, Pan W, Zhang GP, Zhu WH (2006) Heavy metal accumulation from zinc smelters in a carbonate rock region in Hezhang county, Guizhou Province, China. Water Air Soil Pollut 174:321-339

Zabowski D, Henry CL, Zheng Z, Zhang X (2001) Mining impacts on trace metal content of water, soil and stream sediments in the Hei River Basin, China. Water Air Soil Pollut 131:261-273 